\title{
THE PATHOLOGY OF HONEYCOMB LUNG
}

\author{
BY \\ A. G. HEPPLESTON \\ From the Department of Pathology, Welsh National School of Medicine, Cardiff
}

(RECEIVED FOR PUBLICATION DECEMBER 17, 1955)

A form of cystic lung, characterized by numerous, widespread and usually small cavities, is a wellrecognized though apparently uncommon condition, which, according to earlier accounts, occurred especially in children (Sharkey, 1894; Tooth, 1897; Fletcher, 1901; Rernstein, 1905). Such lungs were described by Fowler and Godlee (1898) as having a worm-eaten or honeycomb appearance. Sharkey and Fletcher both believed that the cystic change developed acutely and the condition was generally interpreted as bronchiectasis, bronchiolectasis, or broken-down bronchopneumonic abscesses, thereby implying an acquired origin. To this diffuse form of cystic disease Oswald and Parkinson (1949) also applied the term honeycomb lung and they attempted to establish the nature of the disease process from observations on 16 instances including both children and adults. Having reviewed the literature, these authors concluded that honeycomb lung was probably an acquired inflammatory condition of diverse and often uncertain aetiology, but they were unable to exclude a developmental origin in some instances. Nine of Oswald and Parkinson's cases came to necropsy, and lungs from five, together with the case previously reported by Eernstein (1905), were selected by Cunningham and Parkinson (1950) for pathological investigation. These six cases were chosen because they appeared to have distinct histological features suggesting that they represented stages of the same granulomatous process ending in extensive pulmonary fibrosis and cyst formation. Three other examples of honeycomb lung examined by Cunningham and Parkinson were excluded from their report, since the histological characteristics, though not specified, were different, again suggesting multiple causation for honeycomb lung.

Descriptions of honeycomb lung under other terms may, in the past, have obscured its frequency. For instance, Sandoz (1907) described foetal bronchiectasis in twin sisters, aged 18, in whom the anatomical and histological features were identical with those of honeycomb lung as given, below, while von Stössel (1937) and Rubenstein, Gutstein, and Lepow (1955) each reported two cases of this condition in adults as muscular cirrhosis of the lungs. Furthermore, it seems likely that the cases described by Mallory (1948) as granulomatous pneumonitis were also examples of honeycomb lurg.

I have had the opportunity to study many cases of honeycomb lung, but, in addition to the diffuse form, have repeatedly encountered cases in which the disease affected only parts of the lung. Furthermore, the fibrocystic change was occasionally restricted to small circumscribed areas in the secondary lobules of the lung. The disease process, however, appeared to be the same irrespective of the extent and distribution of the changes. To elucidate further the pathogenesis of honeycomb lung its pathological anatomy was investigated by means of serial sections and the histology examined in detail.

\section{Clinical Features of the Material}

Lung tissue was available from 66 cases, 50 being males and 16 females. The preponderance of males is due to the inclusion of 32 coalworkers, but clinical information concerning them is too meagre to warrant tabulation. Thirty of the coalworkers came from South Wales and two from the U.S.A. Their ages at death ranged from 33 to 86 . The cause of death in the coalworkers, as found at necropsy, included pneumoconiosis (with and without overt pulmonary tuberculosis), carcinoma of various organs including the lung, pneumonia, chronic bronchitis and emphysema, and acute or chronic cardiovascular conditions. Horeycomb lung was the primary cause of death in three coalworkers and their clinical associations appear in Table J.

The clinical features of the 34 cases of honeycomb lung in non-coalworkers are presented in Table II. As material from 12 of these cases was sent to Professor J. Gough from diverse sources, including 
TABLE I

COALWORKERS DYING FROM HONEYCOMB LUNGS

\begin{tabular}{|c|c|c|}
\hline$\underset{(\text { Years })}{\text { Age }}$ & Clinical Associations & Mode of Death \\
\hline 33 & $\begin{array}{l}\text { Repeated spontaneous pneumo- } \\
\text { thoraces for } 3 \text { weeks }\end{array}$ & Pneumothorax \\
\hline $\begin{array}{l}69 \\
74\end{array}$ & $\begin{array}{l}\text { Six months dyspnoea } \\
\text { Ten years cough and dyspnoea }\end{array}$ & $\begin{array}{l}\text { Respiratory failure } \\
\text { Congestive heart failure }\end{array}$ \\
\hline
\end{tabular}

three from the U.S.A., the total number does not reflect a local frequency of honeycomb lung. Although the ages at death ranged from 5 months to 77 years in 18 males and from 13 months to

TABLE II

PATIENTS OTHER THAN COALWORKERS

\begin{tabular}{|c|c|c|c|c|}
\hline $\begin{array}{l}\text { Case } \\
\text { No. }\end{array}$ & Sex & $\begin{array}{c}\text { Age } \\
\text { (Years) }\end{array}$ & Clinical Associations & Cause of Death \\
\hline ises & with & h Non- & ecific Features & \\
\hline 1 & $\mathrm{~F}$ & 41 & Several years dyspnoea & $\begin{array}{l}\text { Congestive heart failure } \\
\text { due to honeycomb lungs }\end{array}$ \\
\hline 2 & $\mathbf{M}$ & 51 & $\begin{array}{l}\text { Four years dyspnoea. } \\
\text { Onset , with " in- } \\
\text { fluenza", }\end{array}$ & , , , \\
\hline 3 & $\mathrm{~F}$ & 52 & $\begin{array}{l}12 \text { years cough and dys- } \\
\text { pnoea with pneumo- } \\
\text { thoraces }\end{array}$ & , \\
\hline 4 & $\mathbf{F}$ & 60 & $\begin{array}{l}\text { Five years cough and } \\
\text { dyspnoea. Onset with } \\
\text { "influenza" }\end{array}$ & $\cdot$ \\
\hline 5 & $\mathrm{~F}$ & 64 & $\begin{array}{l}\text { Three years cough and } \\
\text { dyspnoea. Onset with } \\
\text { herpes zoster }\end{array}$ & , \\
\hline 6 & $\mathrm{~F}$ & 65 & $\begin{array}{l}\text { Five years finger club- } \\
\text { bing, two years dys- } \\
\text { pnoea, and one year } \\
\text { cough }\end{array}$ & ". \\
\hline 7 & $\mathbf{F}$ & 69 & Nine years dyspnoea & \\
\hline 8 & $\mathbf{M}$ & 70 & $\begin{array}{l}\text { One year dyspnoea. } \\
\text { Onset with " in- } \\
\text { fluenza" }\end{array}$ & $\begin{array}{l}\text { Respiratory failure due } \\
\text { to honeycomb lungs } \\
\text { with pronounced ade- } \\
\text { nomatosis }\end{array}$ \\
\hline 9 & M & 36 & Three years dyspnoea & $\begin{array}{l}\text { Pneumothorax and sur- } \\
\text { gical emphysema fol- } \\
\text { lowing lung biopsy with } \\
\text { honeycomb lungs cont- } \\
\text { tributory }\end{array}$ \\
\hline 10 & $\mathbf{F}$ & 63 & $\begin{array}{l}\text { Seven months cough } \\
\text { and dyspnoea }\end{array}$ & $\begin{array}{l}\text { Pulmonary embolism } \\
\text { whilst in congestive } \\
\text { heart failure due to } \\
\text { honeycomb lungs (con- } \\
\text { tributory) }\end{array}$ \\
\hline 11 & $\mathbf{F}$ & 53 & $\begin{array}{l}\text { Two months cough with } \\
\text { haemoptysis }\end{array}$ & Carcinoma bronchus \\
\hline 12 & $\mathbf{M}$ & 53 & $\begin{array}{l}\text { Four months carcinoma } \\
\text { palate }\end{array}$ & $\begin{array}{l}\text { Died under anaesthesia } \\
\text { for block dissection of } \\
\text { neck glands }\end{array}$ \\
\hline $\begin{array}{l}13 \\
14\end{array}$ & $\begin{array}{l}\mathbf{M} \\
\mathbf{M}\end{array}$ & $\begin{array}{l}57 \\
58\end{array}$ & $\begin{array}{l}\text { Six months dyspnoea } \\
\text { Not known }\end{array}$ & $\begin{array}{l}\text { Carcinoma bronchus } \\
\text { Coronary thrombosis }\end{array}$ \\
\hline 15 & $\mathrm{~F}$ & 60 & Ten years asthma & Status asthmaticus \\
\hline 16 & $\mathbf{M}$ & 6 & $\begin{array}{l}\text { Six weeks ocular and } \\
\text { cerebral manifestations }\end{array}$ & Carcinoma bronchus \\
\hline 17 & $\mathbf{M}$ & 61 & $\begin{array}{l}\text { Eight months cardiac } \\
\text { infarction }\end{array}$ & Left ventricular failure \\
\hline 18 & $\mathrm{~F}$ & 62 & $\begin{array}{l}\text { Three weeks vomiting, } \\
\text { abdominal pain, and } \\
\text { oliguria }\end{array}$ & $\begin{array}{l}\text { Uraemia due to sub- } \\
\text { acute glomeruloneph- } \\
\text { ritis }\end{array}$ \\
\hline $\begin{array}{l}19 \\
20\end{array}$ & $\begin{array}{l}\mathbf{M} \\
\mathbf{M}\end{array}$ & $\begin{array}{l}63 \\
71\end{array}$ & $\begin{array}{l}\text { Dyspnoea for years } \\
22 \text { years Addison's dis- } \\
\text { ease of the adrenals }\end{array}$ & $\begin{array}{l}\text { Coronary thrombosis } \\
\text { Cardiac failure due to } \\
\text { Addison's disease }\end{array}$ \\
\hline 21 & $\mathbf{M}$ & 72 & $\begin{array}{l}\text { Many years cough and } \\
\text { dyspnoea }\end{array}$ & $\begin{array}{l}\text { Congestive heart failure } \\
\text { due to generalized em- } \\
\text { physema }\end{array}$ \\
\hline 22 & $\mathbf{M}$ & 73 & Not known & $\begin{array}{l}\text { Sudden cardiac failure } \\
\text { of uncertain nature }\end{array}$ \\
\hline 23 & $\mathbf{M}$ & 77 & None & $\begin{array}{c}\text { Suicide by coal-gas } \\
\text { poisoning }\end{array}$ \\
\hline
\end{tabular}

TABLE II-continued

\begin{tabular}{|c|c|c|c|c|}
\hline $\begin{array}{l}\text { Case } \\
\text { No. }\end{array}$ & Sex & $\begin{array}{c}\text { Age } \\
\text { (Years) }\end{array}$ & Clinical Associations & Cause of Death \\
\hline \multicolumn{5}{|c|}{ Cases with Specific Features } \\
\hline 24 & $\mathrm{~F}$ & 1412 & 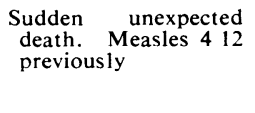 & $\begin{array}{l}\text { Bilateral pneumothor- } \\
\text { aces due to honeycomb } \\
\text { lungs. Generalized } \\
\text { eosinophilic granuloma } \\
\text { at necropsy }\end{array}$ \\
\hline 25 & $\mathbf{M}$ & 36 & $\begin{array}{l}\text { Seven years diabetes in- } \\
\text { sipidus, followed by } \\
\text { organic dementia }\end{array}$ & $\begin{array}{l}\text { Bron h o p n e m onia } \\
\text { with honeycomb lungs } \\
\text { contributory. Eosino- } \\
\text { philic granuloma at } \\
\text { necropsy }\end{array}$ \\
\hline 26 & $\mathbf{M}$ & 35 & Several years dyspnoea & $\begin{array}{l}\text { Congestive heart fail dre } \\
\text { due to honeycomb } \\
\text { lungs. Histology sug- } \\
\text { gests eosinophilic gran- } \\
\text { uloma of the lungs }\end{array}$ \\
\hline 27 & $\mathrm{~F}$ & $\begin{array}{c}\text { Young } \\
\text { adult }\end{array}$ & $\begin{array}{l}\text { Four and a half years } \\
\text { dyspnoea and cough. } \\
\text { Worked in fluorescent } \\
\text { lamp industry }\end{array}$ & $\begin{array}{l}\text { Chronic berylliosis of } \\
\text { the lungs with honey- } \\
\text { combing contributory }\end{array}$ \\
\hline 28 & $\mathbf{M}$ & 512 & $\begin{array}{l}\text { Twenty-five days strep- } \\
\text { tomycin }\end{array}$ & $\begin{array}{l}\text { Tuberculous broncho- } \\
\text { pneumonia }\end{array}$ \\
\hline 29 & $\mathbf{M}$ & 912 & $\begin{array}{l}\text { Three months cough } \\
\text { and failure to gain } \\
\text { weight. Two months } \\
\text { streptomycin and } \\
\text { P.A.S. }\end{array}$ & $\begin{array}{l}\text { Primary pulmonary tu- } \\
\text { berculosis with tuber- } \\
\text { culous bronchopneu- } \\
\text { monia }\end{array}$ \\
\hline 30 & $\mathbf{M}$ & 1312 & $\begin{array}{l}\text { Five months cough and } \\
\text { failure to gain weight. } \\
\text { Three months strepto- } \\
\text { mycin, P.A.S., and } \\
\text { I.N.A.H. }\end{array}$ & $\begin{array}{l}\text { Primary pulmonary tu- } \\
\text { berculosis with tuber- } \\
\text { culous bronchopneu- } \\
\text { monia. Honeycomb } \\
\text { lungs contributory }\end{array}$ \\
\hline 31 & $\mathrm{~F}$ & 51 & Ten years scleroderma & Bronchopneumonia \\
\hline 32 & $\mathrm{~F}$ & 5 & $\begin{array}{l}\text { Ten years scleroderma. } \\
\text { Eight months malig- } \\
\text { nant hypertension }\end{array}$ & Malignant hypertension \\
\hline 33 & $\mathrm{~F}$ & 1112 & $\begin{array}{l}\text { Four weeks cough, } \\
\text { dyspnoea, cyanosis. } \\
\text { Followed chickenpox }\end{array}$ & $\begin{array}{l}\text { Giant-cell pneumonia. } \\
\text { Honeycomb lungs con- } \\
\text { tributory }\end{array}$ \\
\hline 34 & $\mathrm{~F}$ & 39 & $\begin{array}{l}\text { Two years dyspnoea } \\
\text { and pneumothoraces }\end{array}$ & $\begin{array}{l}\text { Honeycomb lungs with } \\
\text { chylous ascites and } \\
\text { right pleural effusion. } \\
\text { Pulmonary leiomyo- } \\
\text { matosis at necropsy }\end{array}$ \\
\hline
\end{tabular}

69 years in 16 females, all except five cases were $\frac{\dot{\sigma}}{3}$ adults. Only 13 out of the total 66 cases were under the age of 50. From Table II it will also $ᄋ$ be seen that honeycomb lung was the underlying cause of death in 11 non-coalworkers and that it $\frac{\text { 의 }}{2}$ was contributory in six others.

\section{METHODS}

In the majority of cases the necropsy was performed $N$ in this or related departments, the whole lung being N fixed by intrabronchial injection of $10 \%$ formalin containing $4 \%$ sodium acetate. The lungs of most of the remaining cases were also fixed in an expanded state. Several blocks were taken from representative areas in $\mathbb{D}$ each case and paraffin sections were stained by haema- ? toxylin-eosin and in most cases for elastin, collagen, and $\square$ reticulin. The periodic-acid-Schiff (P.A.S.) reaction was observed in certain cases and sometimes frozen $\stackrel{\mathbb{D}}{\circ}$ sections were stained for fat with Sudan IV. Six cases $\vec{\Phi}$ (Nos. 9, 13, 19, 25, and 31, Table II, plus that of a coal- 2 worker of 76) were also studied in $20 \mu$ serial sections, prepared as previously described (Heppleston, 1953), and 8 involving the examination of almost 4,000 sections. 


\section{MaCroscopic APPEARANCES}

On section, the cysts are rounded or irregular in shape and vary in size not only between different lung specimens but also in the same lung. The usual range of diameter is $1-10 \mathrm{~mm}$., the smaller sizes being more frequently seen. The cyst walls consist of a coarse network of fibrous or granulation tissue. These changes are sometimes widespread throughout the lung (Fig. 1), but more often they have an irreg.lar or patchy distribution. Both lungs may be affected, though the honeycombing is sometimes more extensive on ore side than the other. Not infrequently a peripheral band of lung 2-5 cm. wide and located posteriorly or basally (Fig. 2) is alone involved. In other cases the changes appear to be more or less segmentally distributed or they may involve only the central portion of a lobe. Sometimes the cysts have a roughly linear arrangement, lying predominantly along septa, vessels or bronchi. Occasionally the cystic change is circumscribed and surrounded by normal lung. In such instances the cysts are related to a central fibrous nodule from which strands of fibrous tissue radiate between the enlarged air spaces (Fig. 3). Circum-

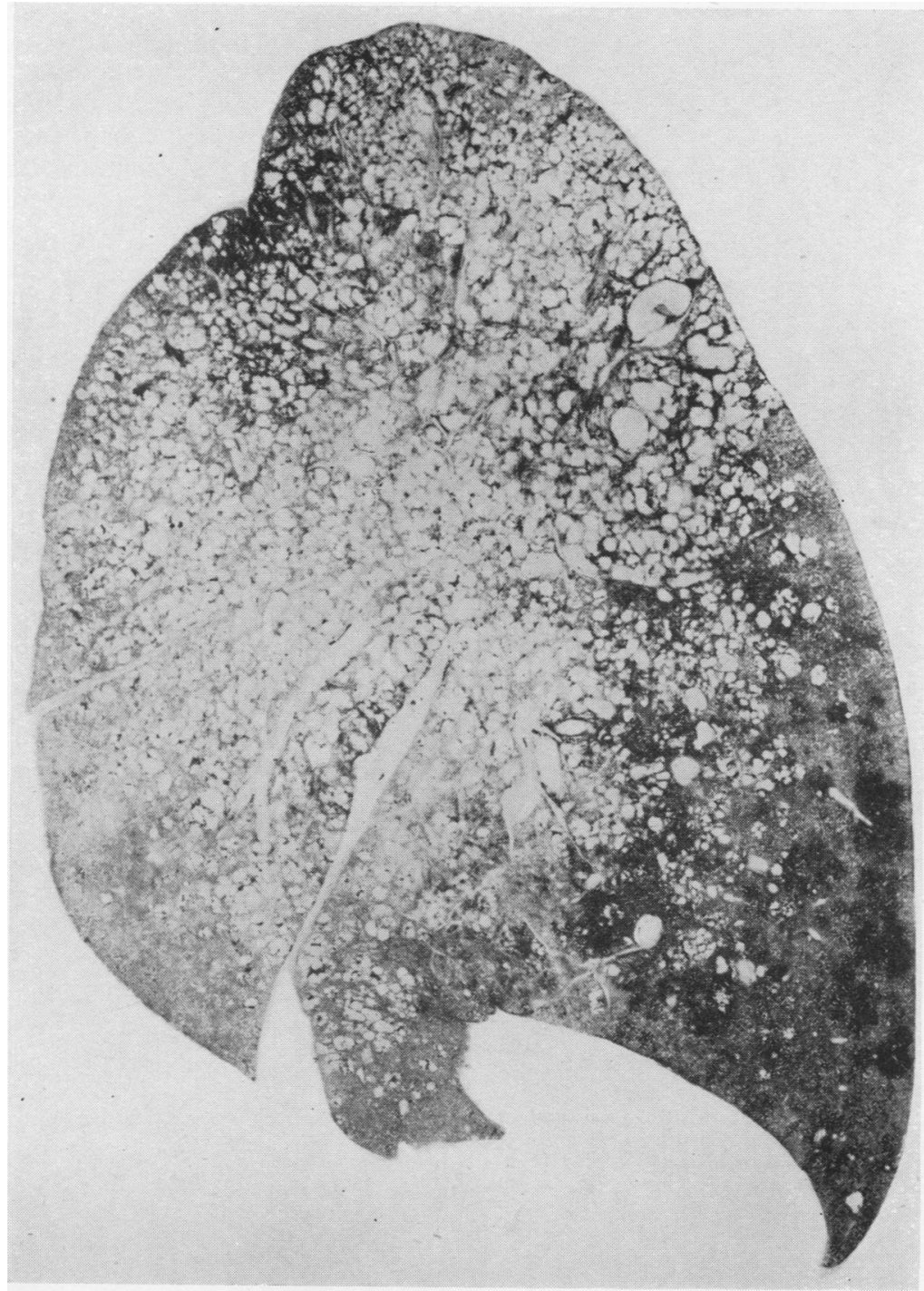

Fig. 1.-Honeycomb lung of widespread distribution in a case (No. 25) of eosinophilic granuloma. Note the discrete circumscribed lesions at the base (see Fig. 6). The dark areas are due to congestion. Whole lung $\times \frac{1}{2}$. scribed lesions occur in lungs showing typical honeycombing elsewhere (Fig. 1). Honeycombed areas may merge into non-cystic, fibrosed lung or show an abrupt transition to normal tissue.

\section{Pathological Anatomy}

By DisseCtion.-The air passages in several fixed specimens were exposed under a dissecting microscope from the hilum to the periphery of the lung. Passages traversing normal lung are not enlarged, but shortly before entering a fibrocystic area slight

or moderate dilatation is sometimes evident and this continues in the diseased zone. There the walls are thickened and from them folds, with a crescentic, circular or spiral disposition, sometimes project into the lumen of dilated airways, giving them a convoluted appearance in longitudinal section. Many air passages, whether dilated or not, can be traced into the peripheral cysts through a wide or narrow orifice. Thick plugs of mucus are frequent at the entry of the air passage into a cyst. Many cysts intercommunicate. Some air 


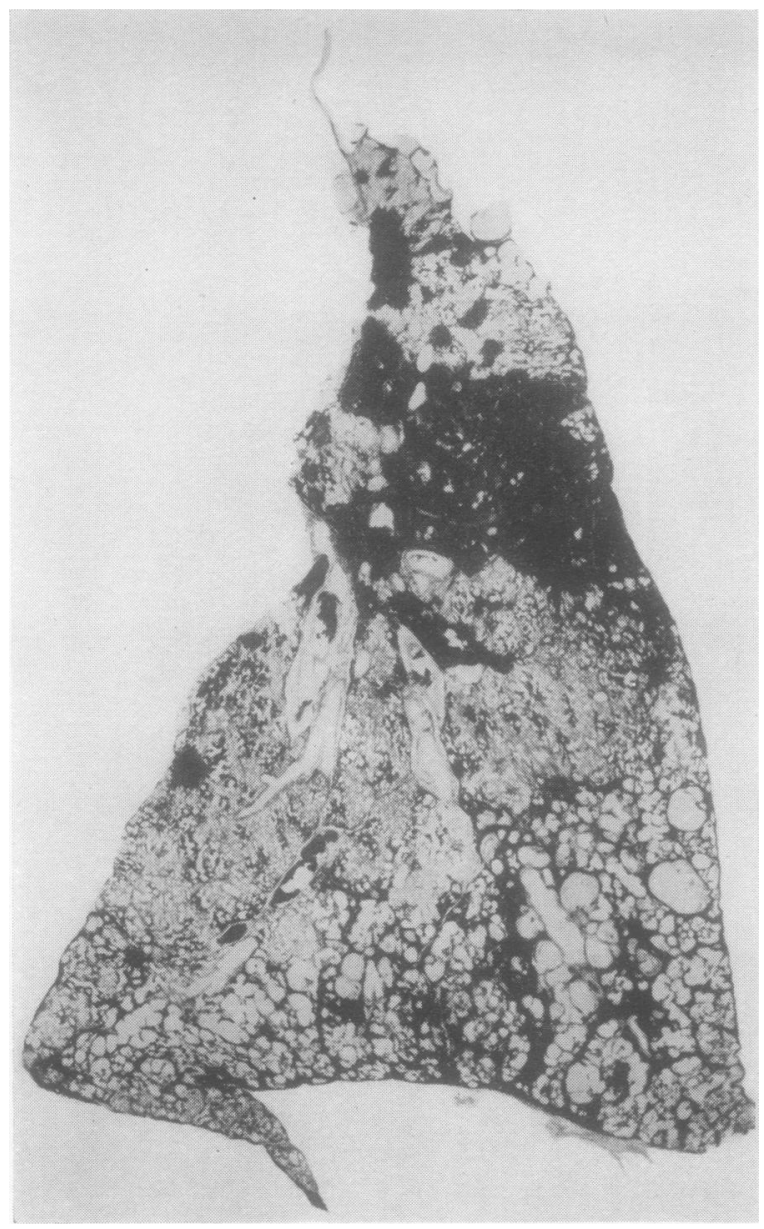

Fig. 2.-Honeycombing restricted to the basal and posterior aspects of the lower lobe from a coalworker's lung. The fibrous tissue between the cysts is deeply pigmented. Coalworkers' pneumoconiosis is also present, massive fibrosis occurring towards the apex of the lobe and simple rneumoconiosis elsewhere. $\times \frac{1}{2}$.

passages, however, do not communicate with cysts but end blindly.

By Serial Sections.-On numerous occasions in each of the six cases studied by means of serial sections, the air passages were followed to the periphery from the smallest bronchi or from bronchioles. Bronchioles may be distinguished by the absence of cartilage from their walls. Normally there are three to five orders of non-respiratory bronchioles between the smallest bronchus and the first order of respiratory bronchiole, as von Hayek (1953, p. 70) also found, and three orders of respiratory bronchiole are customary before reaching the single order of alveolar duct (Heppleston, 1953).
In fully developed honeycomb lung the differen- $\overrightarrow{\bar{N}}$ tiation of non-respiratory from respiratory bron- $\frac{\overrightarrow{0}}{0}$ chioles is not easy owing to obliteration of alveoli $\frac{C}{0}$ and cyst formation, but, by bearing in mind the normal mode of subdivision, it is sometimes possible $\vec{\nabla}$ to distinguish these segments with reasonable certainty. Many bronchioles, evidently non-respiratory, are tortuous, sometimes dilated though $\vec{\circ}$ not narrowed, and communicate freely with the $\overrightarrow{\vec{\omega}}$ smaller cysts, which are surrounded by fibrous tissue (Fig. 4). Many of these cysts are probably $\overrightarrow{\vec{x}}$ derived from respiratory bronchioles, but others appear to originate from non-respiratory bronchioles though not, so far as can be judged, from bronchi. Two or three bronchioles, derived from a common stem two to four segments proximally, sometimes enter the same cyst. Such anastomosis of air passages reflects the destruction of parts of the lung parenchyma. Some cysts, however, usually the larger ones, are not in free communication with the air passages, which as they approach of the cyst are elongated and greatly compressed. Their entry into the cyst is oblique and through a slit-like aperture strongly suggesting a valvular effect (Fig. 5). Occasionally a cyst originates from one side of a greatly compressed bronchiole, which

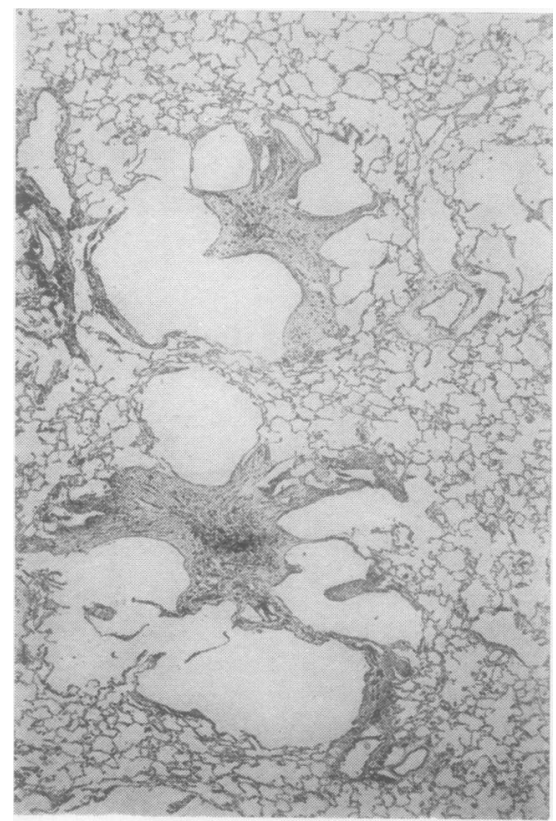

Fig. 3.-Two adjacent areas of the circumscribed type of cystic change. Typical honeycombing is present elsewhere in this lung, together with features suggesting eosinophilic granuloma (see Fig. 19). Coalworker, aged 33, who died from honeycomb ling. Haematoxylin-eosin. $\times 10$. 


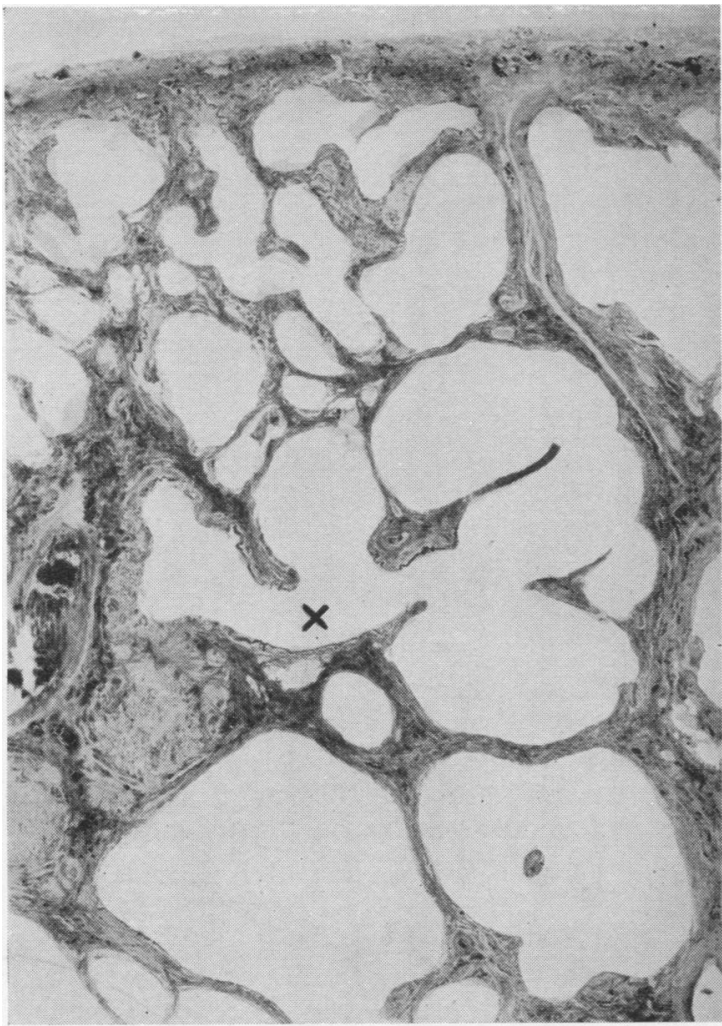

FIG. 4.-Honeycomb lung showing free communication (X) between a bronchiole and a group of small cysts. Case 9 . H.E. $\times 10$.

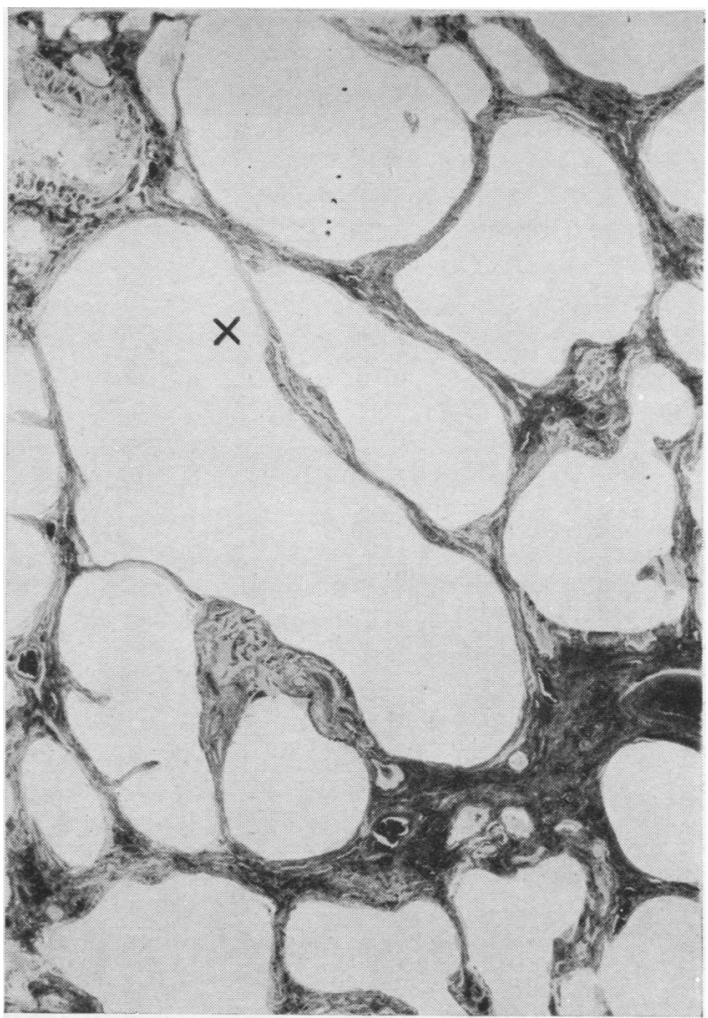

Fig. 5.-Same case as in Fig. 4, but showing a greatly narrowed bronchiole entering (at X) a larger cyst. H.E. $\times 10$.

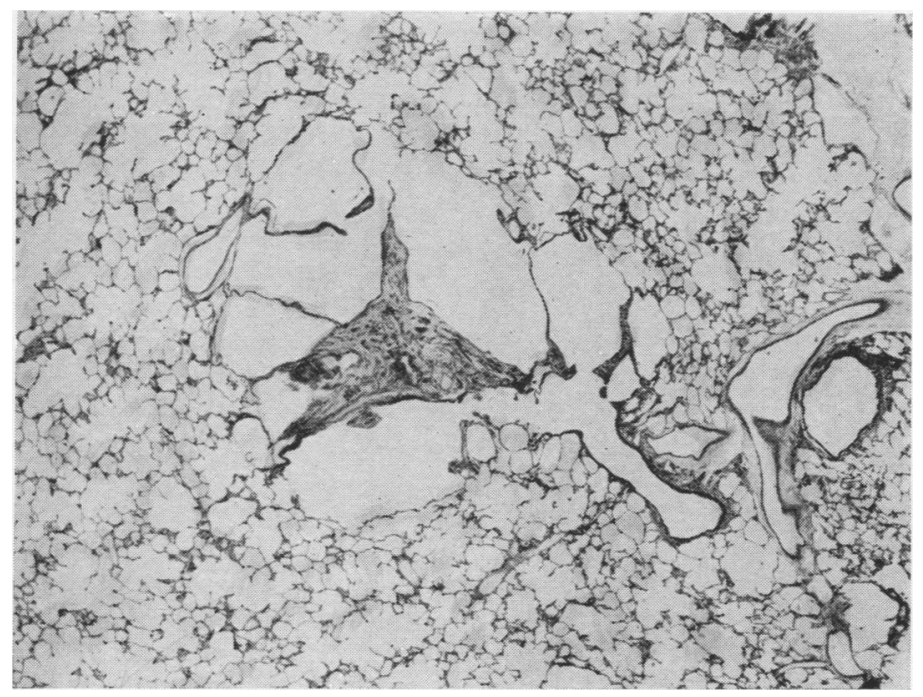

Fig. 6.-Circumscribed lesion with the terminal bronchiole in free communication with dilated respiratory bronchioles. The latter are grouped around a stellate nodule of fibrous tissue. Case 25 . H.E. $\times 10$. 
continues distally as a normal-sized air passage leading freely into other cysts. One cyst often leads into others from which alveolar ducts or alveolar sacs may arise. In this way grape-like bunches of cysts are joined to the same stem bronchiole. The apertures between cysts are usually wide but may ke narrow. Judging by the reduced number of branches at various levels many ramifications of the bronchiolar tree are, on the other hand, completely obliterated, and in this process respiratory bronchioles of all orders and their branches appear to suffer more severely than non-respiratory bronchioles. Some non-respiratory bronchioles terminate blindly after a long or short course in the associated fibrous tissue. A striking feature of some cases, even at the magnification of 30 used for studying the serial sections, is the prominence of smooth muscle bundles coursing through the fibrous areas and surrounding certain of the cysts.

Since the circumscribed form of cystic change could represent an early stage in the disease process, attention was also paid to its anatomy. Some respiratory bronchioles, together with their alveolar ducts and alveoli, have been obliterated and only a stellate fibrous nodule, containing irregularly disposed smooth muscle fibres, remains. Other respiratory bronchioles, derived from the same terminal (non-respiratory) bronchiole as the obliterated ones, are dilated and form the cystic spaces around the fibrous nodule. Proximally, the dilated respiratory bronchioles are in unobstructed communication with the terminal bronchiole (Fig. 6) and, distally, with normal alveolar ducts. It is conceivable that, as the circumscribed lesions increase in size and number, they become confluent and so give rise to fully developed honeycomb lung. The simple dust lesion of coalworkers is distinguished from the circumscribed type of cystic change by the preponderance of dust, the paucity of fibrous tissue, and the patency of all the air passages derived from the terminal bronchiole (Heppleston, 1953).

\section{General Histology}

THE CYSTS.-These vary not only in size and shape but also in their lining epithelium and contents. Some cysts without detectable epithelium are empty as are others with a flattened or cuboidal epithelium. When present, the epithelium is usually of regular columnar type with or without cilia (Fig. 7). It may include mucus-secreting cells and sometimes rests on a basal layer of small cells. Various types of epithelium may line different cysts of the same case or even the same cyst. In six cases the epithe- lial proliferation is greater than necessary simply to line the spaces and assumes a stratifed (Fig. 8) or papillary form (Fig. 9). In six instances (including three with stratified or papillary epithelium) squamous metaplasia is evident (Fig. 10). Alveoli bordering fibrocystic areas occasionally show an epithelial lining. Cysts commonly contain mucus which is P.A.S.-positive and in which phagocytic histiocytes occur. The latter are sometimes foamy, when frozen sections reveal sudanophil fat in the cytoplasm. Giant cells, often containing dust and sometimes cholesterol crystals, may be found in the cysts. Giant cells can also be seen on occasion in the cyst epithelium, where they probably arise by fusion of cells, and in the interstitial tissues of some cases. Eosinophils may occur inside the cysts and a terminal acute inflammatory exudate is not infrequent.

Interstitial Changes in Cystic AREas.-Irregularly shaped masses or strands of fibrous tissue lie between the cysts, but some alveoli may persist in the fibrocystic zones. The fibrosis is both reticular and collagenous and of loose or compact texture. It is well vascularized by capillaries and venules, and fibroblasts are present in varying number. A light or dense infiltration of inflammatory cells occurs, tending to be denser in the less fibrous areas and vice versa. Lymphocytes and plasma cells predominate, but eosinophils may be conspicuous and a scattering of histiocytes and neutrophil polymorphs is frequently seen. Although the cellular infiltration is usually diffuse, focal accumulations are not uncommon. Phagocytes laden with carbonaceous pigment are scattered throughout the fibrous areas, the larger accumulations occurring in coalworkers (Fig. 2). The features of the pigmented, fibrous component of honeycomb lung in these men do not as a rule resemble those of massive fibrosis which characterizes complicated pneumoconiosis (Heppleston 1951a), though sometimes only the presence of smooth muscle distinguishes the fibrosis of honeycomb lung. Apart from the smooth muscle often evident around the cysts, large and small bundles or isolated fibres are commonly seen in varying amount in the fibrous tissue (Fig. 11). In some areas the muscle bundles are irregularly disposed, but in other places they appear to originate from obliterated air passages and blood vessels. An origin from pre-existing structures cannot account for all the interstitial muscle in many of the cases; hyperplasia of smooth muscle must therefore be regarded as being common in honeycomb lungs. This is emphasized by the existence in some lungs, 


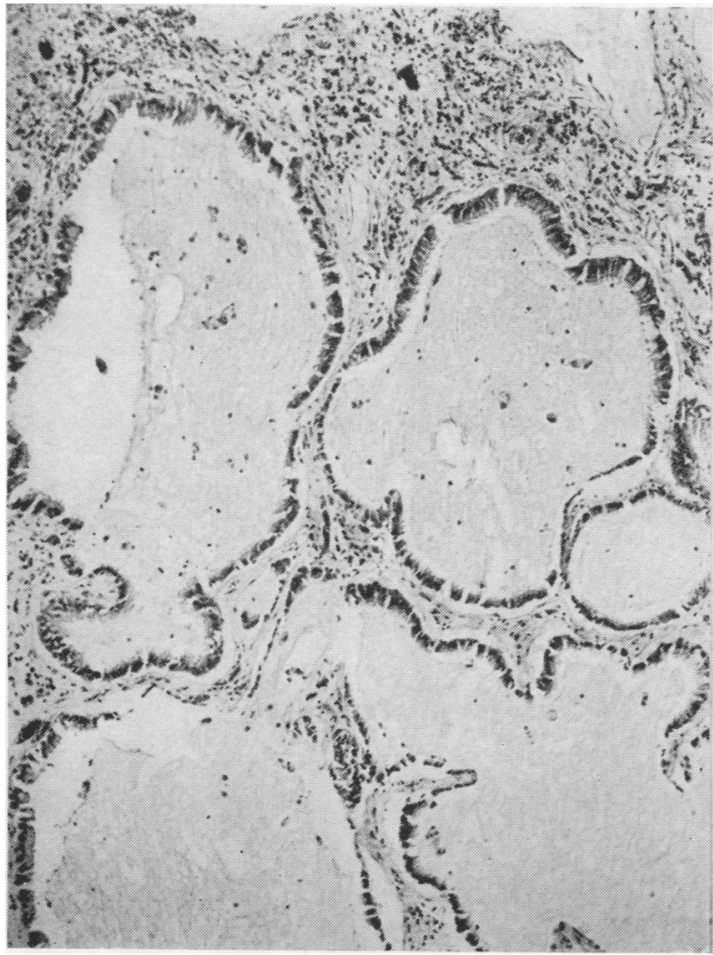

FIG. 7.-Cilisted epithelium, including mucin-secreting cells, lining cystic spaces. Case 19 . H.E. $\times 70$.

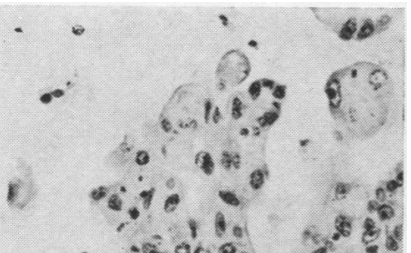

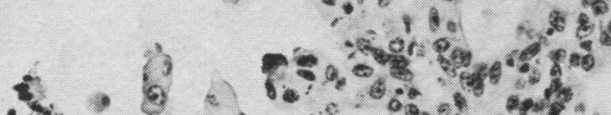

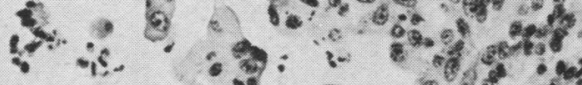

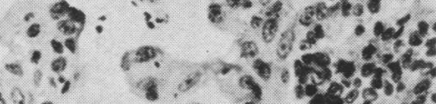

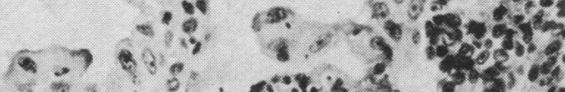

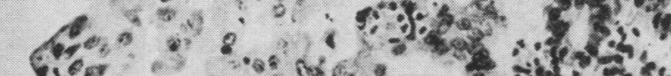
Vien, $\therefore 3=:$ o- o

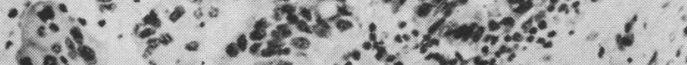

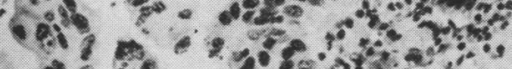
: 2 i

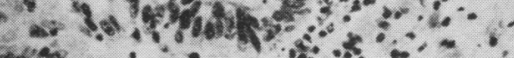

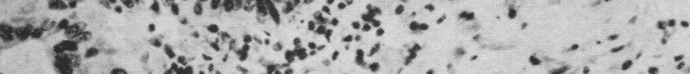

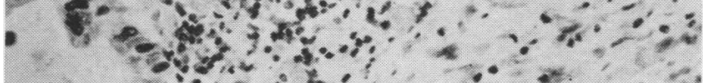

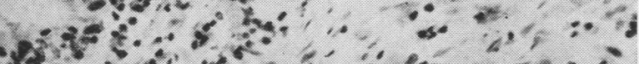

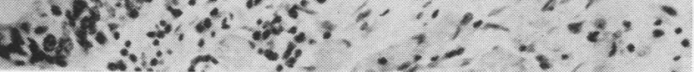

FIG. 9.-Adenomatosis with papillary epithelium lining the cysts. Case 8. H.E. $\times 150$.

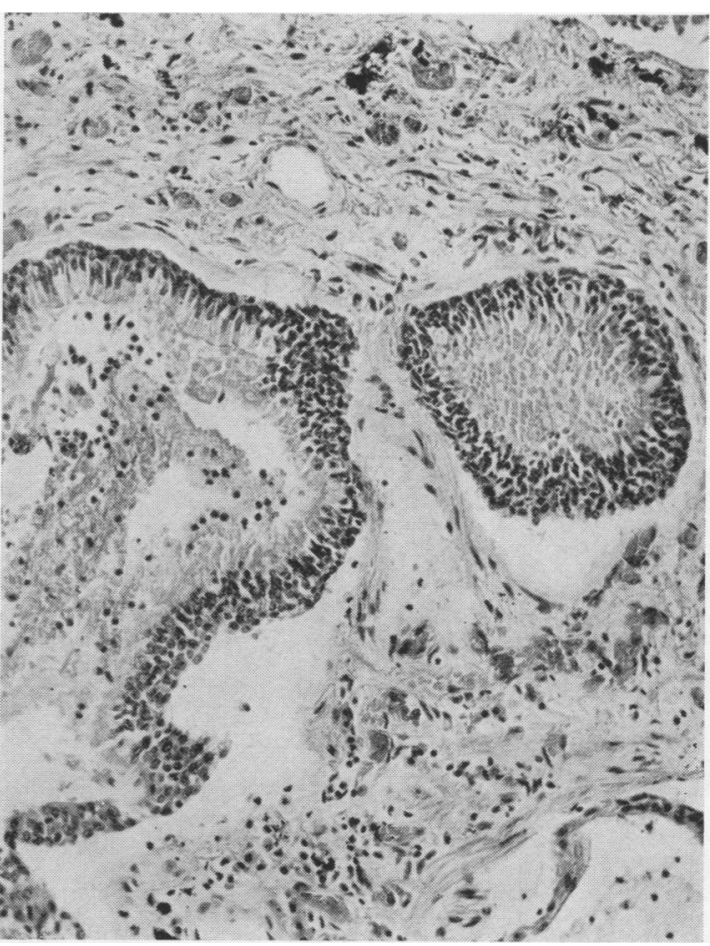

Fig. 8.-Adenomatosis with stratified epithelium lining the spaces. Case 20. H.E. $\times 150$.

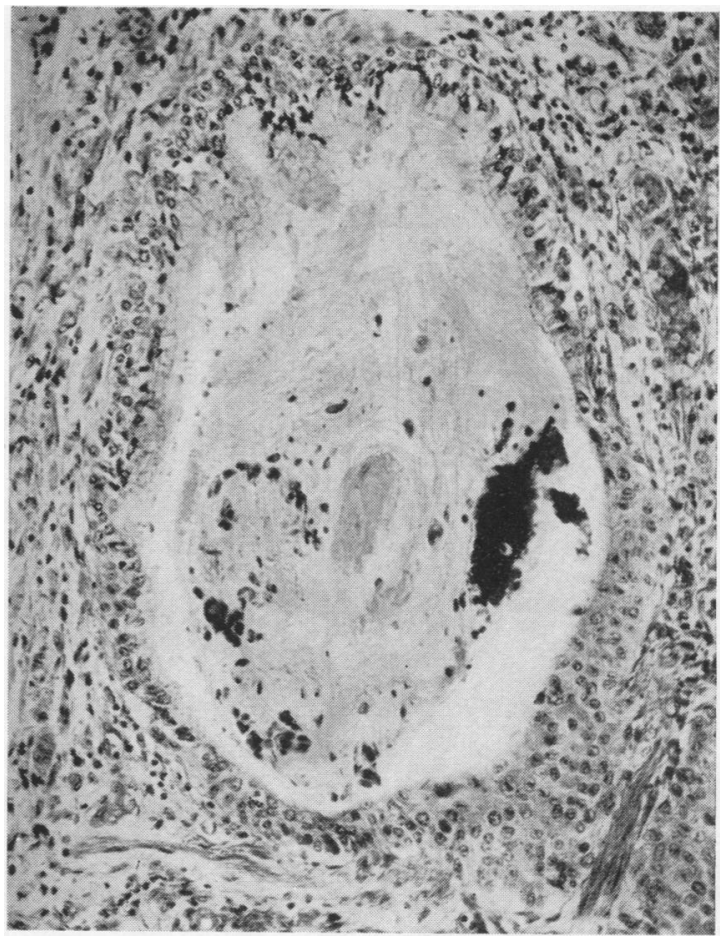

FIG. 10.-Squamous metaplasia in epithelium which is ciliated or mucin-secreting elsewhere in the same space. Case 5. H.E. $\times 150$ 


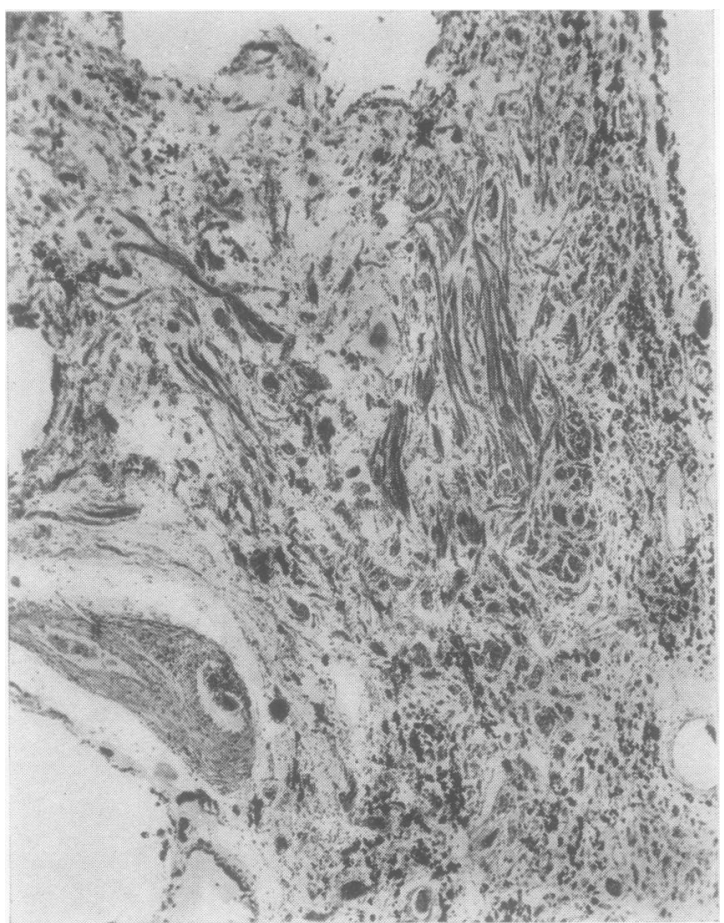

Fig. 11.-Bundles of smooth muscle fibres lying in the fibrous com ponent of honeycomb lung. Coalworker. H.E. $\times 35$.

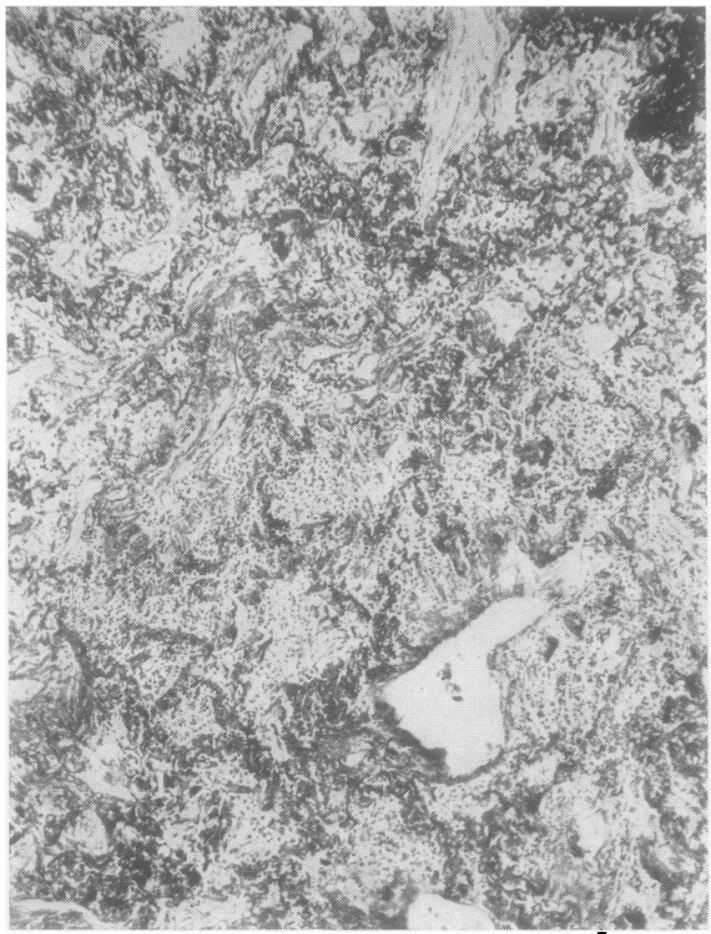

FIG. 13.-Fibrous area in a honeycomb lung, showing an elastin pattern resembling that of expanded parenchyma. Case 12 . Verhöff. $\times 70$.

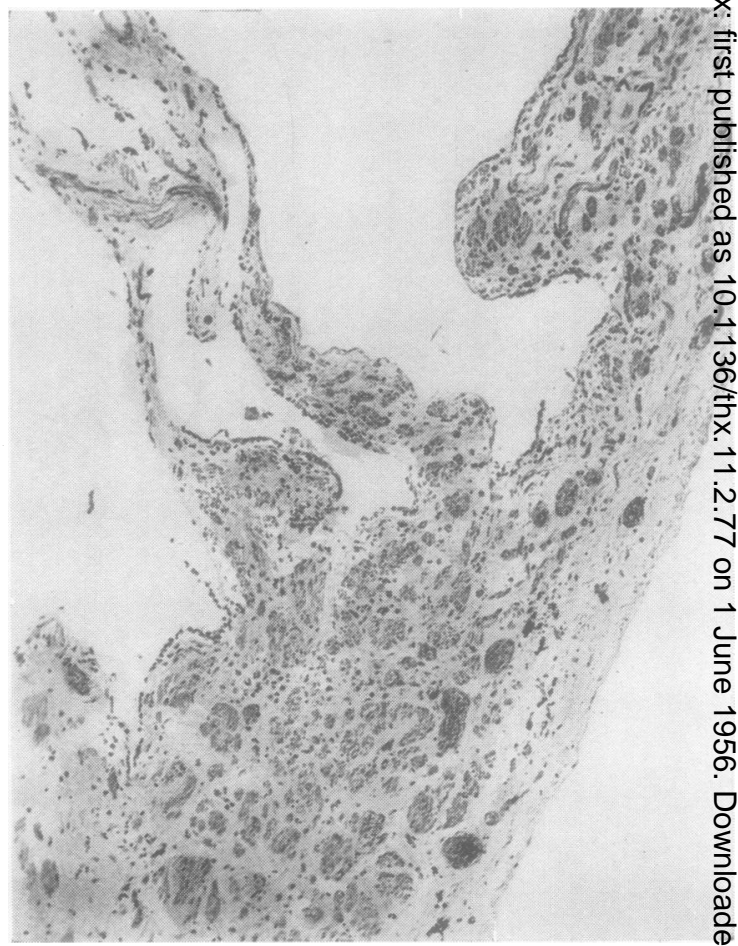

FIG. 12.-Subpleural concentration of smooth muscle bundles. Case 19. H.E. $\times 70$.

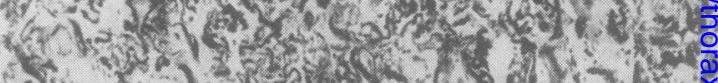

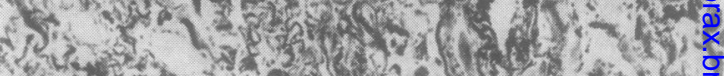

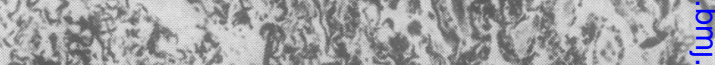

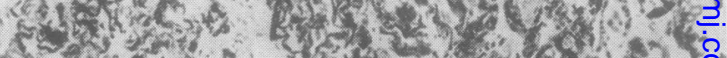

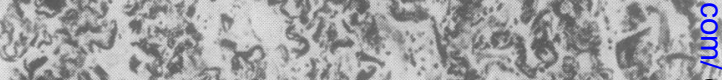

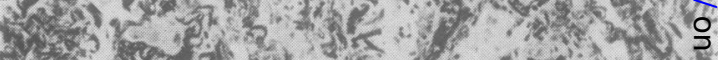
vota chang

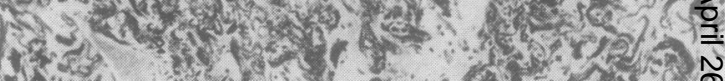

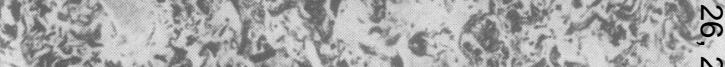

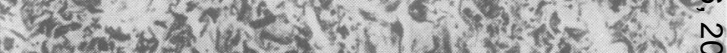
ind 2 -

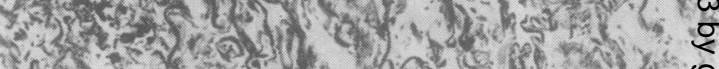
What wis -305.620 .

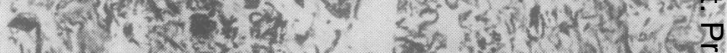

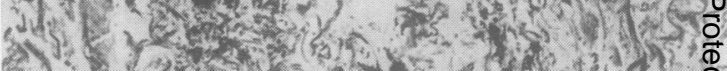

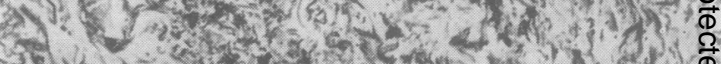
36-2.

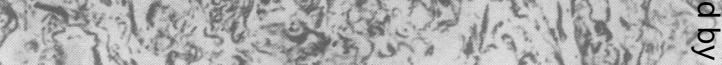

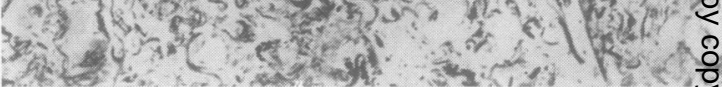

FIG. 14.-Another fibrous area in which the elastin pattern resembles. that of collapsed lung. Coalworker. Verhöff. $\times 70$. 
especially subpleurally, of concentrations of muscle in which numerous bundles run in parallel (Fig. 12). Elastic tissue is always present and frequently prominent in the fibrous areas, either as single strands, small knots, or as dense, tangled masses or bands. Undoubtedly much of the elastic tissue is derived from obliterated bronchioles, alveoli, and blood vessels, but hyperplasia appears to contribute in the denser areas. The pattern of the elastic fibres sometimes corresponds to that of more or less normally expanded alveoli, alveolar ducts, or respiratory bronchioles (Fig. 13), while in other places the pattern is that of collapsed alveoli (Fig. 14). Arterioles and small arteries traversing the fibrous zones often show obliterative endarteritis which may be severe. In lung tissue so disorganized it is impossible to say whether these vessels belong to the pulmonary or bronchial system. Bronchopulmonary anastomotic arterioles, the "Sperrarterien" of von Hayek (1953, p. 230), do not appear to be more prominent than usual.

INTERSTITIAL Changes in Non-CYSTIC AREAS.Where honeycombing affects only parts of the lung, the remainder may be normal or show other histological changes. Interstitial reticulin fibrosis of alveolar walls (Figs. 15 and 16) is present to a varying degree and extent in 15 cases. This change has a patchy distribution even within secondary lobules and is associated with a pleomorphic cellular infiltration. In places a transition can be traced from normal lung through a zone of increasingly severe interstitial fibrosis to the denser fibrosis associated with honeycombing of the lung (Fig. 17). At the same time many alveoli are evidently overrun by reticulin fibrosis, but some alveoli persist and may develop an epithelial lining. Areas of interstitial fibrosis of alveolar walls also occur at a distance from honeycombed parts of the lung and adjacent to or between the patches of fibrosis small cysts may be seen. These findings suggest that patchy interstitial fibrosis develops into honeycomb lung rather than that interstitial fibrosis represents a peripheral extension of the fibrotic component of honeycomb lung. To establish this interpretation, discontinuity between areas of interstitial fibrosis and fibrocystic change must be demonstrated in three dimensions, but this was not possible with the present material. There is no evidence to suggest how the interstitial fibrosis originates.

\section{Specific Histological Features}

The appearances detailed above are in whole or in part common to 53 of the cases in this series and in all of them the changes are non-specific. Thirteen cases, however, show changes in the lungs or in other organs suggesting a more precise origin.

EosinophILIC GranUloma.-Eosinophilic granuloma is known to involve extraskeletal tissues, among them the lung (Thannhauser, 1950; Lichtenstein, 1953), and to become increasingly fibrous in the retrogressive or chronic phase (EngelbrethHolm, Teilum, and Christensen, 1944). Honeycomb lungs are sometimes associated with this granuloma (Rowland, 1928; Farber, 1942; Oswald and Parkinson, 1949; Parkinson, 1949; MacDonald and Shanks, 1954; Grant and Ginsburg, 1955). Honeycomb lungs were found by McKeown (1954) in two infants with Letterer-Siwe disease, which is now generally regarded as an acute form of eosinophilic granuloma (Farber, 1942; Mallory, 1942; Lichtenstein, 1953). Cunningham and Parkinson (1950) thought that their cases of diffuse cystic lungs could fit into the eosinophilic granuloma group.

Two cases of the present series are undoubted examples of eosinophilic granuloma with extrapulmonary lesions and two others may well represent instances of eosinophilic granuloma confined to the lungs.

Case 24 (Table II) was that of a child who died suddenly and without prior illness from bilateral spontaneous pneumothoraces. At necropsy eosinophilic granuloma of the acute type involved the thymus, liver, spleen, lymph nodes, thyroid, and salivary glands as well as the lungs. The latter show numerous focal infiltrations of histiocytes (devoid of sudanophil fat) with some admixture of lymphocytes, eosinophils, and fibroblasts. Fibrosis, however, is slight and mainly interstitial. Many of these granulomatous foci, especially in the upper parts of the lungs, are related to cysts measuring up to $5 \mathrm{~mm}$. across (Fig. 18). In the liver the infiltration is periportal and associated with early proliferation of bile ducts and acute cholangitis. Eosinophils are most conspicuous in the thymus.

Case 25 (Table II and Fig. 1) was previously reported by Spillane (1952, Case 3). Diabetes insipidus was the presenting clinical feature, and at necropsy the hypothalamus contained eosinophilic granuloma. In parts of the lungs the honeycombing is associated with fibrosis and appears non-specific, but other parts are more cellular, eosinophils and histiocytes being more in evidence.

In one of the coalworkers, who died from honeycomb lungs at the age of 33 , the cysts are situated in relation to a granulomatous reaction in which histiocytes and eosinophils are prominent (Fig. 19) and among which giant cells occur. Necropsy revealed no extrapulmonary lesions.

Case 26 (Table II) resembles the preceding one, but in parts the interstitial changes are more fibrous.

SARCoIDosis.-The lung of one coalworker aged 47 shows follicular granulomata with giant cells 


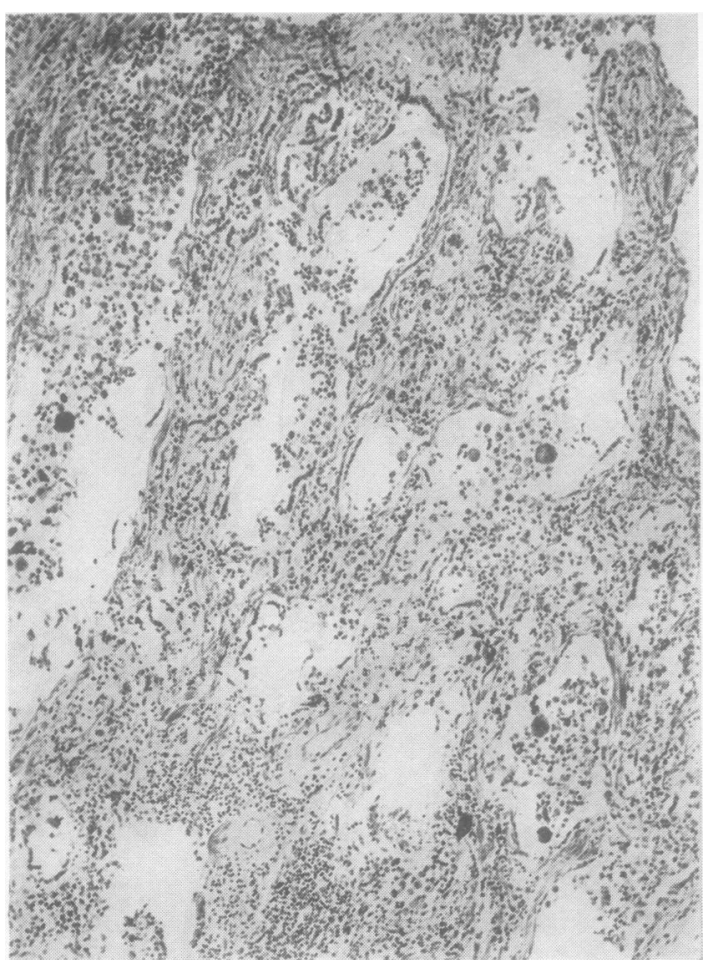

Fig. 15.-Interstitial changes in an area without cysts of a lung with honeycomb features elsewhere. Note the intra-alveolar giant cells. Case 15. H.E. $\times 70$.

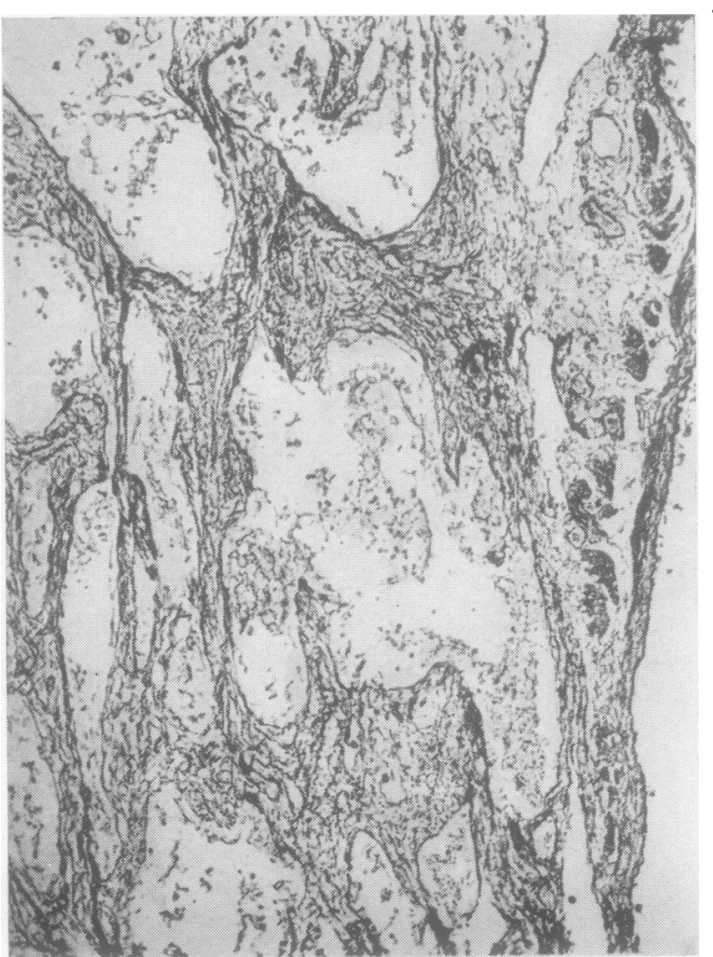

FIG. 16.-Same case as in Fig. 15, but stained to show reticulin fibrosis of alveolar walls. Reticulin. $\times 70$.

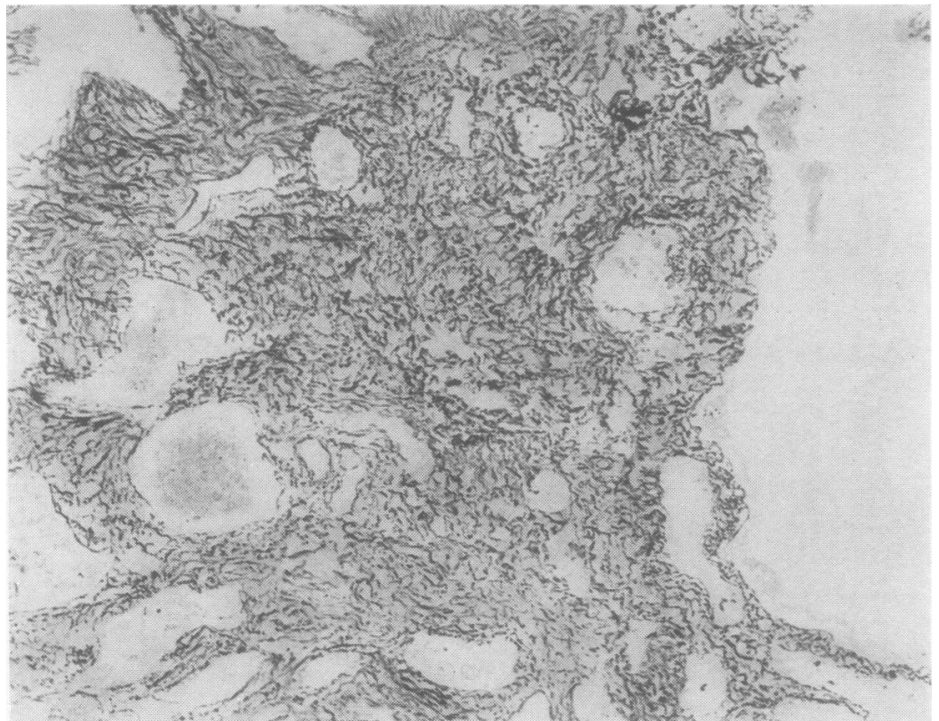

FIG. 17.-Transition from interstitial reticulin fibrosis of alveolar walls (left) to the more solid fibrosis adjacent to a cyst (right). In the process alveoli are being overrun. Case 13. H.E. $\times 70$. 


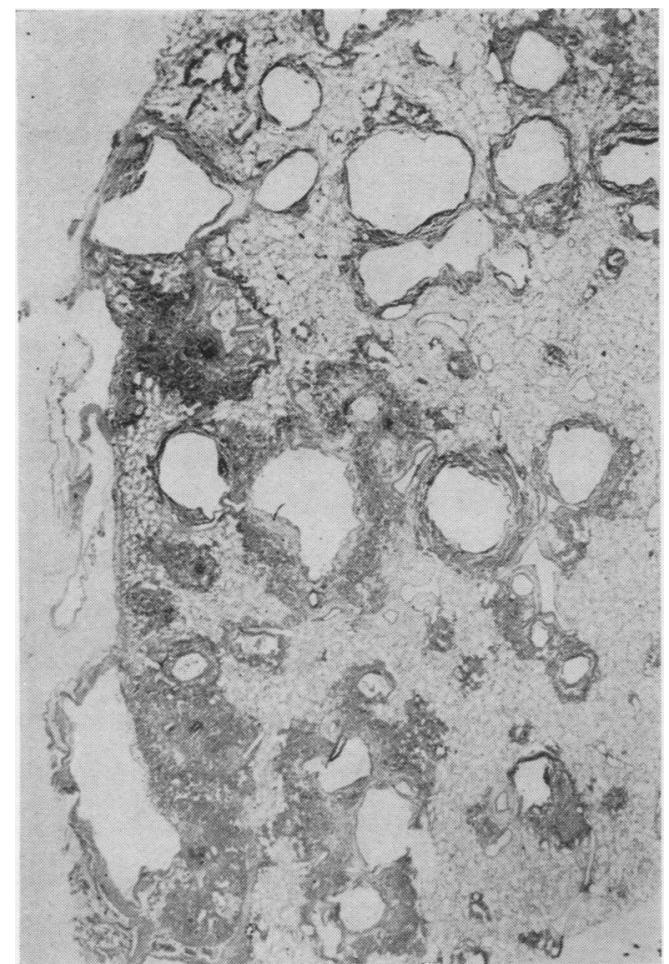

FIG. 18.-Cyst formation in relation to foci of acute eosinophilic granuloma of the lung. Case 24. H.E. $\times 4$.

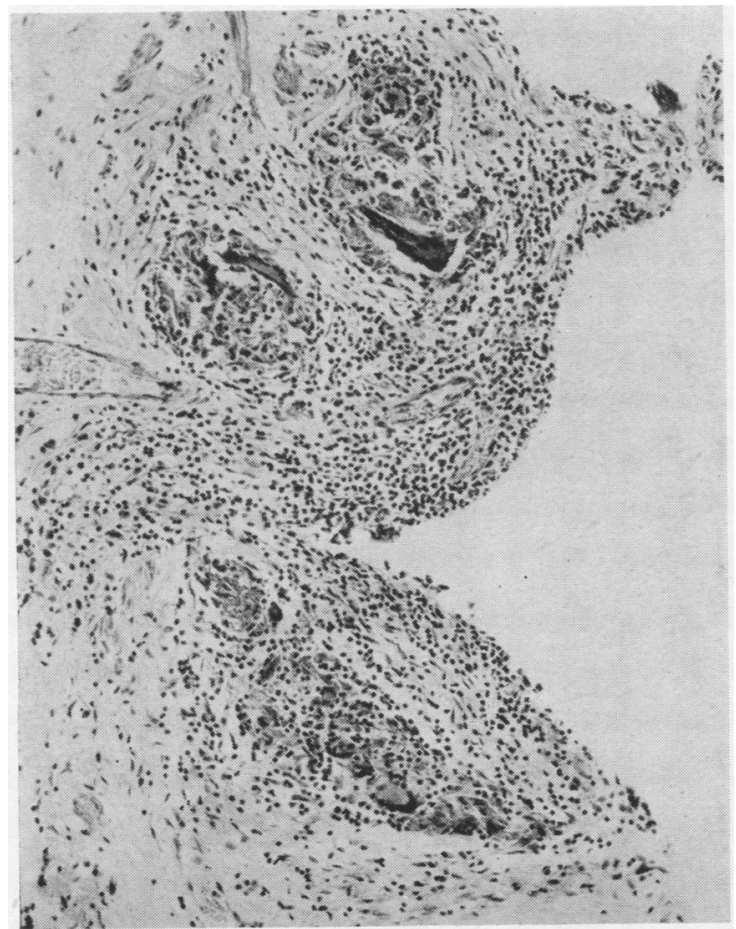

Fig. 20.-Sarcoid follicles lying in the fibrous tissue between cysts. Coalworker. H.E. $\times 120$.

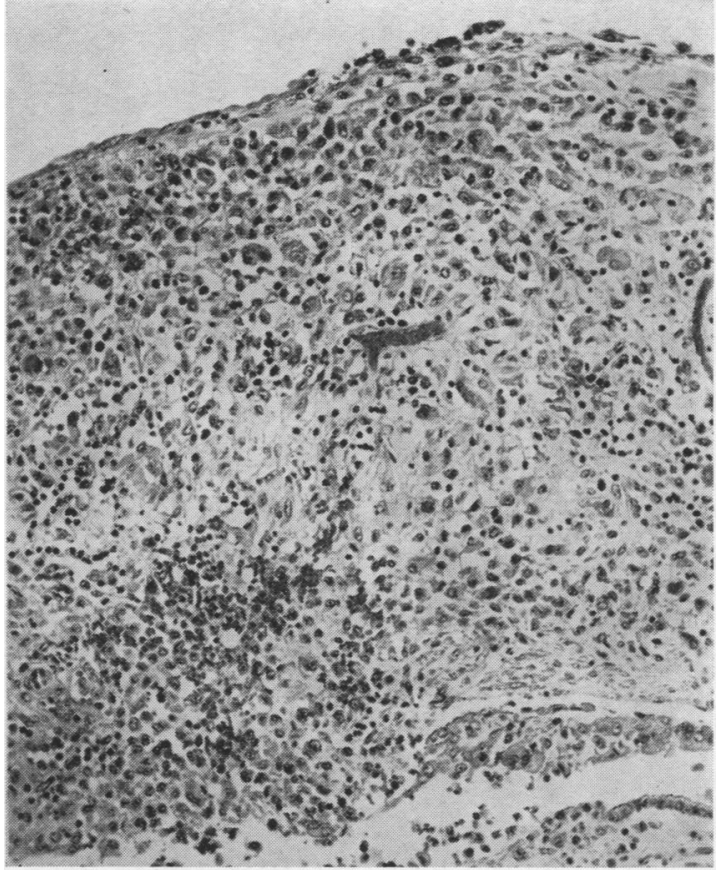

FIG. 19.-Granulomatous reaction, including histiocytes and eosinophils, forming the wall of a cyst. Same case as in Fig. 3. H.E. $\times 150$.

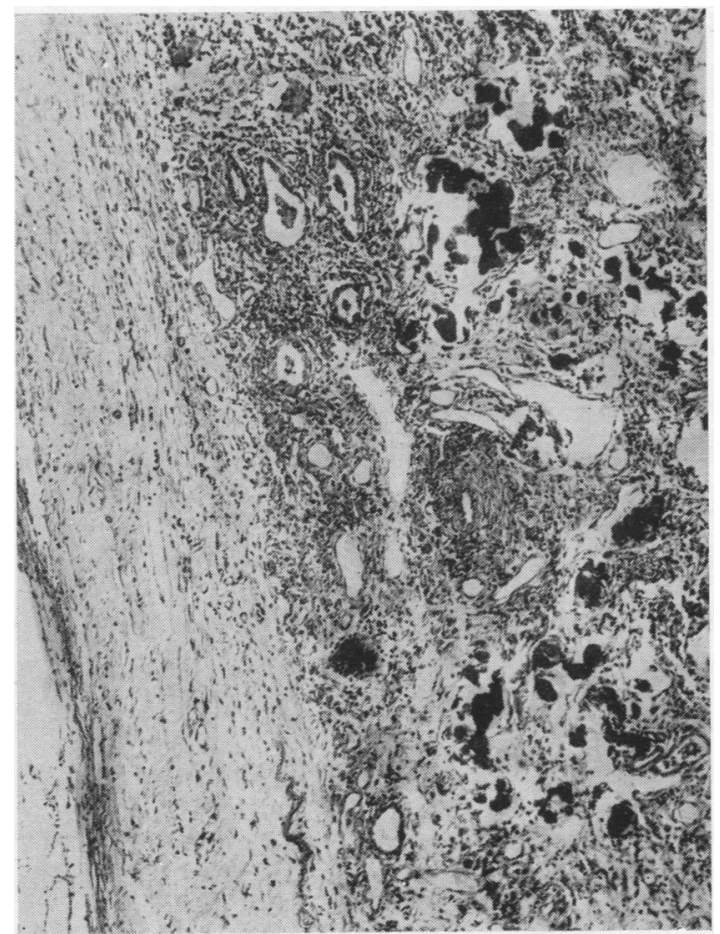

FIG. 21-Berylliosis. Granulomatous reaction, with many darkly staining conchoidal bodies, adjacent to the fibrous wall of a cyst. Case 27. H.E. $\times 70$. 


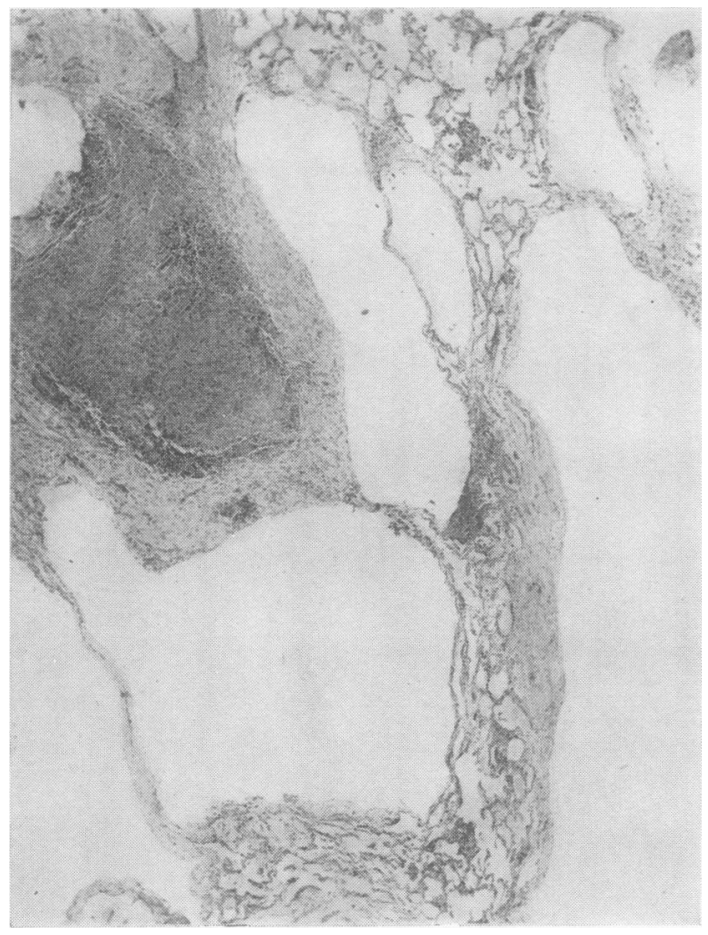

FIG. 22.-Tuberculous granuloma with cyst formation after streptomycin therapy. Case 30. H.E. $\times 20$.

lying in the fibrous tissue which separates the cysts (Fig. 20). Similar granulomata occur in the hilar glands, and the appearances strongly suggest pulmonary sarcoidosis.

BeRYLliosis.-Beryllium pneumonitis is characterized by a focal and diffuse histiocytic reaction in which giant cells and conchoidal bodies are often numerous (Hardy and Tabershaw, 1946; Dutra, 1948). Material provided by Dr. Harriet Hardy from two cases of this disease occurring in the U.S.A. includes one (No. 27, Table II) that shows fibrous-walled cysts in relation to the usual granulomatous reaction (Fig. 21) and also considerable interstitial fibrosis of alveolar walls.

TUBERCULOUS BRONCHOPNEUMONIA.-Tuberculous bronchopneumonia that had been treated with streptomycin was associated with honeycomb lung in three young children (Cases 28, 29, and 30, Table II). All these cases occurred recently, and the development of honeycombing no doubt depends on the longer period of survival when tuberculous bronchopneumonia is treated with streptomycin and isoniazid. In these cases a patchy granulomatous reaction, with reticulin fibrosis and occasional tubercles, is often related to cysts

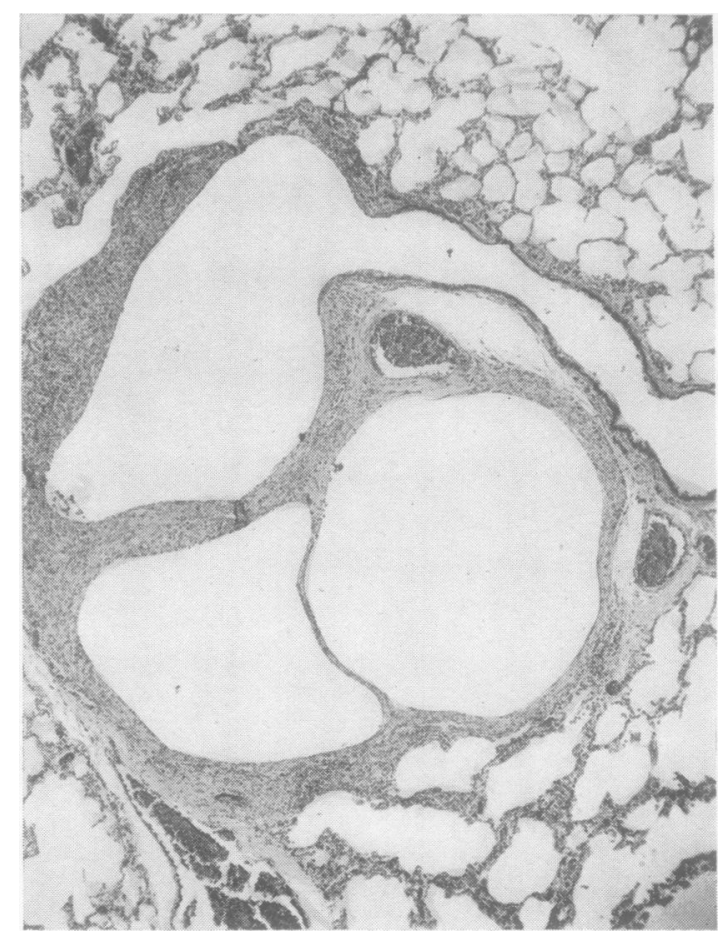

FIG. 23.-Non-respiratory bronchiole entering, without obstruction, one of a group of cysts. These have developed in strict relationship to a focus of tuberculous bronchopneumonia. Case 29. H.E. $\times 35$.

measuring 1-10 mm. across (Fig. 22). Fig. 23 from Case 29 shows a non-respiratory bronchiole entering, without obstruction, a small cyst of a circumscribed group, but a valvular mechanism is probably responsible for producing the larger cysts, seen especially in Case 30 . In places the granulomatous and fibrous elements involve the alveolar walls interstitially. Debré (1952) mentions three similar cases. The radiological phenomenon of "vanishing lung" in tuberculous lesions treated by streptomycin or isoniazid (Rappaport, 1955) may perhaps be connected with the development of honeycombing.

SCleroderma.-Honeycomb lung is sometimes associated with scleroderma (Evans and Parker, 1954), and these lesions coexisted in two cases (Nos. 31 and 32, Table II). In one the atypical reaction of the pulmonary collagen to Van Gieson's stain resembled that sometimes seen in the skin, but in other respects the histological features of the lungs are not distinctive.

Giant-Cell PNeumonia.-Interstitial pneumonia of giant-cell type, as described by Hecht (1910), may also be combined with cystic change (Case 33, Table II). Small cysts occur tetween patches of 


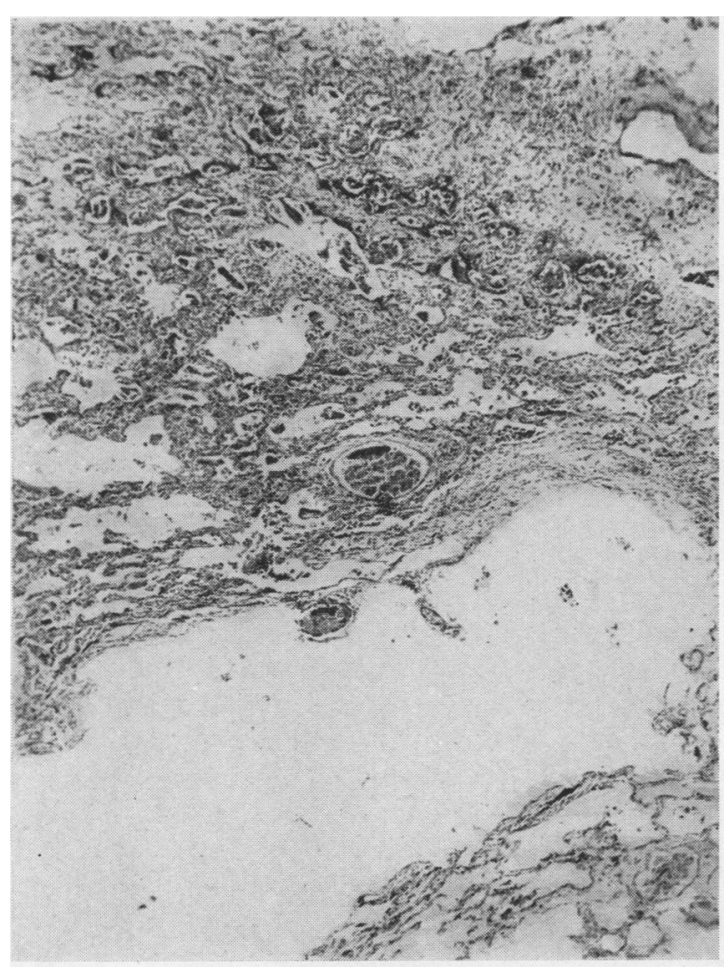

FIG. 24.-Giant-cell pneumonia in a child showing interstitial changes with cyst formation. Case 33. H.E. $\times 35$.

pneumonia (Fig. 24) but not where consolidation is widespread. Reticulin fibrosis involves the alveolar walls and extends up to the cysts, but confluent fibrosis is minimal and very few alveolar spaces are obliterated. These features lend support to the view that patchy interstitial fibrosis may progress to honeycombing of the lung. Many of the giant cells contain inclusion bodies of differing sizes, a finding peculiar to this one case in the series.

LEIOMYOMATOSIS.-The hyperplastic muscle often seen in honeycomb lungs is situated within fibrous areas, but Case 34 (Table II) is peculiar in that fibrosis is inconspicuous whereas hyperplasia of smooth muscle is pronounced and constitutes the essential pathological feature. So great an increase in muscle suggests a primary condition and warrants the term leiomyomatosis. This change, though not uniform throughout the lung, appears to be largely confined to the respiratory segments of the airway, especially affecting bronchioles but not sparing alveolar structures. Many of these air passages are cystic, their greatly thickened walls consisting of smooth muscle (Fig. 25) with a supporting network of fine reticulin and a few strands of elastic

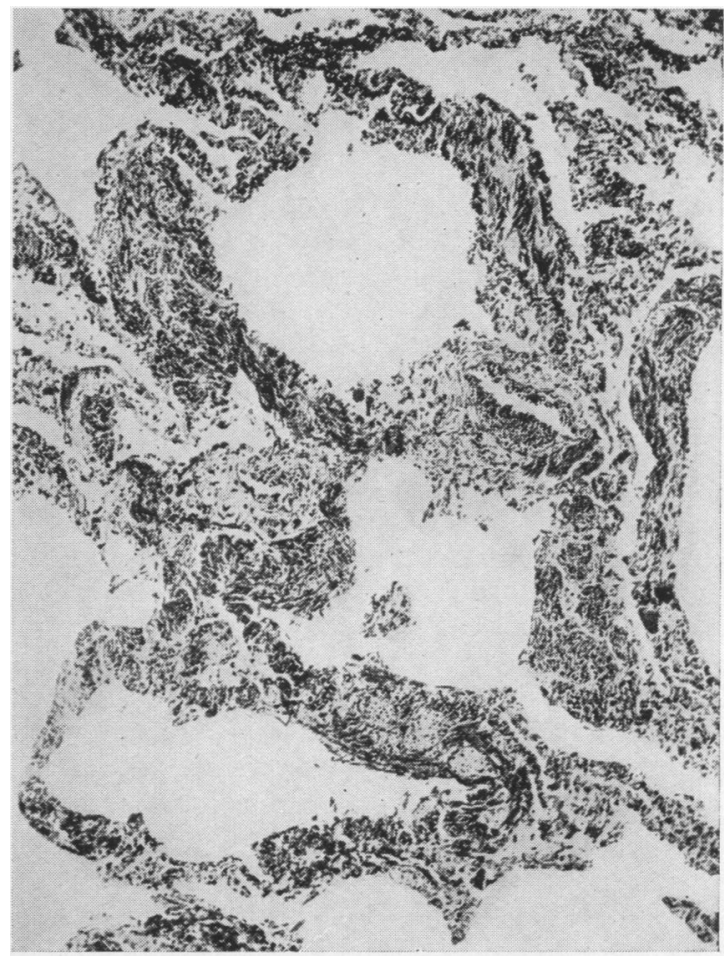

FIG. 25.-Pulmonary leiomyomatosis with cystic change. All the darkly stained elements are smooth muscle fibres. Case 34. Lissamine red-tartrazine. $\times 70$.

tissue as the only fibrous components. Occasionally lymphoid foci are seen in the muscular walls. The number of branches arising at various levels of the bronchiolar tree seems to be reduced. A normal alveolar structure remains in parts of the lung, but some alveolar walls remote from the muscular areas show a little fibrous thickening.

\section{LIVER LESIONS}

Liver and pulmonary involvement by eosinophilic granuloma often coexist, especially in children (Rowland, 1928; Farber, 1942 ; Oswald and Parkinson, 1949; Thannhauser, 1950; MacDonald and Shanks, 1954), and the girl aged 16 months (Case 24, Table II) provides another example of this combination. Biliary cirrhosis or pericholangitis is described as a further hepatic lesion found in cases of honeycomb lung in children (Fletcher, 1901 ; Bernstein, 1905; Oswald and Parkinson, 1949). In the present series liver material was available for histology in 20 of the 61 cases in adults. Five individuals, four of whom were coalworkers, showed a mild or moderate degree of periportal fibrosis and chronic inflammatory cell infiltration with proliferation of bile ducts. 


\section{Discussion}

The cysts of honeycomb lungs have been found only in association with other pathological changes. Occasionally these take the form of granulomata such as eosinophilic granuloma, sarcoid, berylliosis, or tuberculosis. Rarely interstitial giant-cell pneumonia or myomatosis constitutes the associated lesion. In the majority of instances, however, cysts develop in relation to fibrosis, which lacks specific features. It is, nevertheless, possible in many cases to suggest certain general processes leading to fibrosis.

One means, as indicated above, appears to be interstitial fibrosis of alveolar walls and respiratory air passages. This change has a patchy distribution and cysts may therefore develop in adjacent uninvolved lung tissue. Histologically, the interstitial fibrosis of alveolar walls seen in some honeycomb lungs resembles the Hamman and Rich (1914) form of pulmonary interstitial fibrosis (Heppleston, $1951 \mathrm{~b}$ ), but in the latter the changes are widespread throughout the lungs. Mild enlargement of air spaces may be seen in the Hamman and Rich condition, but frank cyst formation is not mentioned by Pokorny and Hellwig (1955), who referred to 31 published instances and added one of their own. This is presumably because no unaffected parenchyma remains where cysts may develop. Collapse of lung tissue may also contribute to the development of the fibrosis in honeycomb lungs, as is shown by the obliteration of many respiratory and nonrespiratory bronchioles as well as by the pattern of elastic fibres in some fibrous zones (Fig 14). In other fibrous zones, however, the disposition of elastic fibres resembles that of normal lung (Fig. 13), which suggests that the solid fibrosis could have arisen either from interstitial fibrosis of alveolar walls or from organization of an intra-alveolar exudate (Heppleston, 1951b). Unresolved bronchopneumonia, following influenza, measles, or pertussis, could lead to patchy bronchiolar obstruction and obliteration (Winternitz, Wason, and McNamara, 1920; Opie, Blake, Small, and Rivers, 1921; Blumgart and MacMahon, 1929; Engel, 1947), alveolar collapse and carnification. In four cases dying from honeycomb lung, symptoms began immediately after " influenza" (Cases 2, 4, and 8, Table II) and herpes zoster (Case 5, Table II), but in no other case was an antecedent condition recognized. The association of recognized granulomata with honeycomb change clearly indicates the origin of the fibrosis in certain cases. The occurrence of honeycombing in cases of tuberculous bronchopneumonia treated with streptomycin and in giantcell pneumonia shows that under some circumstances the cysts may take relatively little time to form. In $\overrightarrow{\bar{D}}$ the cases descrited above as non-specific the $\bar{\partial}$ character of the cellular infiltration in the fibrotic zones does not suggest eosinophilic granuloma and no extrapulmonary granulomatous lesions of eosinophilic type are known to exist. The fibrous phase of eosinophilic granuloma may, however, lack specific features, as Case 25 shows, and the lung alone may be involved. It is thus impossible to assess the part played by pulmonary eosinophilic granuloma in the production of fully developed honeycomb lung. The circumscribed cystic lesions may also ke explained on the basis of organized granulomatous or bronchopneumonic foci. The occurrence in five cases of a hepatic lesion best described as non-obstructive biliary cirrhosis could similarly represent the healed phase of a periportal granuloma now devoid of specific features. Almost half the cases of honeycomb lung in the present series occurred in coalworkers, but no conclusion is yet possible regarding the aetiological significance of this particular occupation.

To meet the objection that honeycomb lung represents the result of infection in congenital cystic disease, the fibrous component must be established as the primary change. The preceding considerations leave little doubt about the acquired nature of the fibrosis, and it is also clear that cystic enlargement of air passages only begins in those parts of the lung affected by granulomata or fibrosis. If the cysts were congenital, they would sometimes be expected to occur alone, but in the present series they are always accompanied by other lung changes and these, on the other hand, may occur independently. In the light of the observations of Norris and Tyson (1947), however, the pathological anatomy of honeycomb lung is decisively in favour

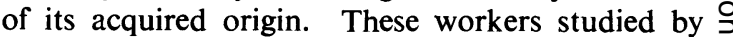
serial sections two cases of cystic lung that were $\rightarrow$ undoubtedly congenital, one case being a stillborn foetus of 6 lunar months and the other a full-term $N$ infant dying from respiratory failure four and a half hours after birth. All the cysts so traced were 0 completely isolated from the bronchial tree, though $\mathrm{\omega}$ anastomoses between cysts were frequent. In ore case Norris and Tyson found many bronchioles with blind terminations in non-cystic parts of the $ळ$ lung and they also noted the absence of inflammatory exudate. These observations contrast with the findings in honeycomb lung.

Pulmonary fibroses or granulomata may therefore be regarded as the usual antecedents of honey- $\stackrel{\mathbb{Q}}{2}$ comb lung, to produce which particular segments of the airway must be obliterated. The anatomical $ᄋ$ observations show that these are some of the non- 
respiratory and respiratory bronchioles together with their subdivisions. In areas overrun by granulomata or fibrosis the normal respiratory movements are prevented. Bronchioles uninvolved by fibrosis or granulomata but adjacent to immobilized areas then undergo compensatory dilatation, no doubt in consequence of locally exaggerated inspiratory traction. Contraction of fibrous tissue and localized collapse of lung will augment the dilatation. Cysts are not evident in the presence of diffuse interstitial fibrosis or where all respiratory spaces have been obliterated. In effect the change may be described as a bronchiolectasis, which is usually saccular and involves both respiratory and non-respiratory bronchioles, and in the production of which some lung parenchyma is destroyed. A secondary factor, however, appears to be responsible for the production of the larger cysts. Evidence pointing to a valvular obstruccion where bronchioles enter certain cysts has been adduced (Fig. 5). The features strongly suggest that as the cysts increase in size under the traction of inspiration, the bronchioles from which they originate are stretched and compressed so that the communication between bronchioles and cysts is tangential or oblique. In this way the exit of air from such cysts is likely to be impeded much more than its entry, with the effect of increasing considerably the size of the cysts. These conclusions regarding the pathogenesis of honeycomb lung thus substantiate and amplify those of von Stössel (1937), Oswald and Parkinson (1949), and Cunningham and Parkinson (1950).

The occurrence of hyperplasia and hypertrophy of smooth muscle in fibrosing pulmonary disease has been reviewed and a series of cases described by I-eibow, Loring, and Felton (1953), who concluded that the fundamental factors concerned are obscure but that increased tissue tension may play a part. Hyperplasia of the muscle in honeycomb lung could well represent a compensatory mechanism of the lung designed to encourage expulsion of air from the cysts, although the irregular disposition of the fibres suggests that their contraction will not produce a co-ordinated effect. A valvular obstruction to the egress of air can only serve to increase the resistance to muscular contraction and thereby provide a further stimulus to hyperplasia. Honeycomb lungs with smooth muscle hyperplasia and with considerable interstitial fibrosis occur in tuberous sclerosis (Berg and Vejlens, 1939; Samuelsen, 1942; Berg and Nordenskjöld, 1946), the hyperplasia of muscle in the lungs being regarded as a part of the general disease process. Licht (1942) reported honeycomb lungs with fibrosis and smooth muscle hyperplasia as an isolated finding in a woman whose daughter had tuberous sclerosis clinically, and he considered the mother was also an example of this condition. Dawson (1954) described a case of tuberous sclerosis in which biopsy showed cystic lung with a great increase in connective tissue, many blood vessels, and some smooth muscle. The fibrous and muscular changes in these five cases of tuberous sclerosis appear indistinguishable from those in non-specific honeycomb lungs, which, however, differ in that chronic inflammatory cell infiltration is frequent and no lesions were found in the brain, skin, kidneys, or heart to suggest tuberous sclerosis in 50 cases in which full details of the necropsies are available.

The amount of smooth muscle in the case of pulmonary leiomyomatosis (Case 34, Table II, Fig. 25) far exceeds that seen in any other instance of honeycomb lung and for this reason it must be placed in a separate category. The only comparable example I have found in the literature is that of Rosendal (1942), who observed cystic lungs with diffuse myomatosis confined to the lungs and hilar glands. The pathogenesis is obscure, although Rosendal considered tuberous sclerosis to be a possibility despite the absence of characteristic lesions in the other organs of his case. Cruickshank and Harrison (1953) found a chondromatous hamartoma of the lung in association with honeycombing and fibro-leiomyomatous change, and they thought the latter was also hamartomatous. No such combination occurred in the present series.

Epithelialization of the cysts, though variable in type, is common and often widespread. Continuity between the epithelium of the bronchioles and that lining cysts is usually evident and epithelialization probably proceeds from the bronchioles. In most instances the epithelial proliferation is limited to the formation of a simple lining to the cysts. This process may therefore be described as simple epithelialization and it occurs as a consequence of fibrosis and cyst formation. The degree of proliferation was, however, excessive in six cases of honeycomb lung, being greater than necessary merely to line the cysts and resulting in a thick stratified or papillary epithelium for which the term adenomatosis appears justified. The distinction between adenomatosis, with its implication of neoplasia, and simple epithelialization is important, since Laipply, Sherrick, and Cape (1955, Figs. 2 and 7 ) illustrate changes indistinguishable from simple epithelialization under the designation of bronchiolar adenoma, a term which they use synonymously with adenomatosis and many other terms. Although admitting that the 


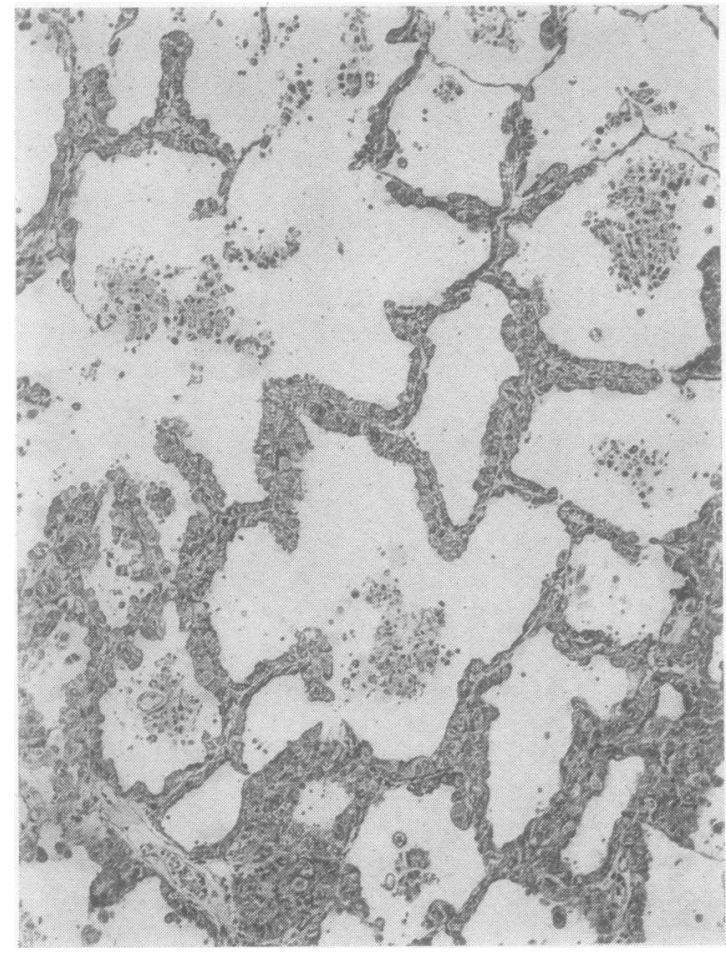

FIG. 26.-Primary pulmonary adenomatosis. Epithelium, in parts showing early papillary formation, lines air spaces of approximately normal size. H.E. $\times 70$.

features in certain of their cases suggested bronchiolectasis and chronic pneumonitis, Laipply and others ruled out an inflammatory basis because bronchiectasis was infrequent, carcinomatous change sometimes occurred, and small lesions lacked inflammation. This difference in interpretation may be resolved if two points are agreed. First, simple epithelialization, whether in honeycomb lung or in non-cystic pulmonary scars, should be excluded from the category of adenomatosis. In such fibrotic or fibrocystic conditions bronchiectasis will not be frequent, since alveolar tissues are predominantly involved. Secondly, it is suggested that the term pulmonary adenomatosis, even when used in this restricted sense, covers more than one condition. It may follow simple epithelialization of spaces in fibrotic lung, as in a few of the present cases, or epithelium of columnar or mucin-producing type may grow over more or less normal alveolar walls. In the latter case the epithelial change appears to be primary, the lesions often being nodular and multiple with little if any inflammatory reaction (Fig. 26). Local growth of epithelium in primary pulmonary adenomatosis could lead to (a) extension over wider areas of alveolar and bronchiolar surfaces; (b) expansion of air spaces already involved, with compression of surrounding structures and almost inevitably with some degree of parenchymal destruction; (c) papillary formations or stratification of the epithelium. If condition (b) predominates it is possible to visualize epithelial proliferation as the cause of cyst formation, and fibrosis could be associated as a secondary stromal reaction. Thus, exceptional cases of honeycomb lung might develop as a consequence of primary epithelial changes, giving rise to appearances such as those observed in certain parts of Case 8 (Table II, Fig. 9). None of the examples of adenomatosis or squamous metaplasia in this series of honeycomb lungs had progressed to malignancy.

\section{SUMMARY}

Based on a series of 66 cases, an account is given of the pathological anatomy and histology of honeycomb lung, an acquired form of cystic disease which may involve the lung focally, irregularly, or diffusely. In most instances honeycombing was an incidental finding of limited extent, but honeycomb lung was the basic cause of death in $\mathbf{1 4}$ cases and was partially responsible for death in six others.

The essential change is regarded as being obliteration, by fibrosis or granulomata, of some of the bronchioles, non-respiratory and respiratory, together with their subdivisions. It is suggested that neighbouring bronchioles not so affected then undergo compensatory dilatation to form cystic spaces in contiguity with the consolidated or fibrotic areas. Secondary valvular obstruction of bronchioles communicating with the cysts is probably responsible for their progressive enlargement.

The fibrous component of honeycomb lung is believed to arise in several ways. Patchy interstitial fibrosis of alveolar walls can apparently be associated with cystic enlargement of air passages in adjacent areas of non-fibrosed lung and the interstitial fibrosis may merge with typical honeycomb lung. Fibrosis may also develop on the basis of organized bronchopneumonia, restricted areas of pulmonary collapse, and certain specific granulomata including eosinophilic granuloma, sarcoidosis, berylliosis, and tuberculosis after streptomycin therapy. Giant cell pneumonia and pulmonary leiomyomatosis are rare associations with honeycomb lung, which may also coexist with scleroderma.

Hyperplasia of smooth muscle is commonly seen in honeycomb lungs. Since a similar combination may be found in tuberous sclerosis, this condition 
must be considered in the differential diagnosis of honeycomb lungs.

A distinction is drawn between the frequent simple epithelialization of spaces in the lung and the rarer adenomatosis. Adenomatosis is held to represent an excessive degree of epithelial proliferation, which may follow simple epithelialization of cystic or non-cystic spaces in fibrotic lung or occur as a primary epithelial change without antecedent fibrosis. Primary pulmonary adenomatosis could conceivably give rise to honeycombing of the lung. Squamous metaplasia also occurs in honeycomb lung, but in none of the cases with adenomatosis or metaplasia had the epithelial proliferation become malignant.

For permission to include their cases in this series thanks are due to Professor C. V. Harrison and Drs. W. H. Beasley, A. C. Counsell, C. K. Davenport, L. Dunner, L. L. Friedman, L. W. Hale, Harriet L. Hardy, J. D. Heppleston, T. D. S. Holliday, R. A. Parker, Tessie Phillips, R. M. E. Seal, R. H. Smart, and G. S. Smith and the late Dr. William Susman. Mr. J. P. Napper was responsible for the photography. I am most grateful to Professor J. Gough, who gave me the benefit of his criticism and advice.

\section{REFERENCES}

Berg, G., and Nordenskjöld, A. (1946). Acta med. Scand., 125, 428. Berg, and Vejlens, G. (1939). Acta paediat. (Uppsala), $26,16$.

Bernstein, J. M. (1905). Trans, path. Soc. Lond., 56, 330.

Blumgart, H. L., and MacMahon, H. E. (1929). Med. Clin. N. Amer., $13,197$.

Cruickshank, D. B., and Harrison, G. K. (1953). Thorax, 8, 316.

Cunningham, G. J., and Parkinson, T. (1950). Ibid., 5, 43.

Dawson, J. (1954). Quart. J. Med., n.s., 23, 113.
Debré, R. (1952). Lancet, 2, 545.

Dutra, F. R. (1948). Amer. J. Path., 24, 1137.

Engel, S. (1947). The Child's Lung, p. 54. Arnold, London.

Engelbreth-Holm, J., Teilum, G., and Christensen, E. (1944). Acta med. Scand., 118, 292.

Evans, M., and Parker, R. A. (1954). Thorax, 9, 154.

Farber, S.' (1942). New Engl. J. Med., 226, 394.

Fletcher, H. M. (1901). Trans, path. Soc. Lond., 52, 193.

Fowler, J. K., and Godlee, R. J. (1898). The Diseases of the Lungs, p. 143. Longmans, Green, London.

Grant, L. J., and Ginsburg, J. (1955). Lancet, 2, 529.

Hardy, H. L., and Tabershaw, I. R. (1946). J. industr. Hyg., 28, 197.

Hayek, $\mathbf{H}$. von (1953). Die menschliche Lunge. Springer, Berlin.

Hecht, V. (1910). Beitr. path. Anat., 48, 263.

Heppleston, A. G. (1951a). Arch. industr. Hyg., 4, 270.

(1951b). Thorax, 6, 426. (1953). J. Path. Bact., 66, 235

Laipply, T. C., Sherrick, J. C., and Cape, W. E. (1955). A.M.A. Arch. Path., 59, 35.

Licht, E. de Fine (1942). Acta radiol. (Stockh.), 23, 151

Lichtenstein, L. (1953). A.M.A. Arch. Path., 56, 84.

Liebow, A. A., Loring, W. E., and Felton, W. L. (1953). Amer. J. Path., 29, 885.

MacDonald, A. M., and Shanks, R. A. (1954). Arch. Dis. Childh., $29,127$.

McKeown, F. (1954). J. Path. Bact., 68, 147

Mallory, T. B. (1942). New Engl. J. Med., 227, 955.

- (1948). Radiology, 51, 468.

Norris, R. F., and Tyson, R. M. (1947). Amer. J. Path., 23, 1075.

Opie, E. L Blake, F. G., Small, J. C and Rivers, T. M. (1921) Epidemic Respiratory Disease, pp. 264 and 340. Kimpton, London.

Oswald, N., and Parkinson, T. (1949). Quart. J. Med., n.s. 18, 1.

Parkinson, T. (1949). Brit. med. J., 1, 1029.

Pokorny, C., and Hellwig, C. A. (1955). A.M.A. Arch. Path., 59, 382.

Rappaport, I. (1955). J. Amer. med. Ass., 158, 1436.

Rappaport, I. (1955). J. Amer.med. Ass., 158, 1436.

Rosendal, T. (1942). Acta radiol. (Stockh.), 23, 138.

Rubenstein, L., Gutstein, W. H., and Lepow, H. (1955). Ann. intern. Med., 42, 36.

Samuelsen, E. (1942). Acta radiol. (Stockh.), 23, 373.

Sandoz, E. (1907) Beitr. path. Anat., 41, 495.

Sharkey, S. J. (1894). St. Thomas's Hosp. Rep., 1892-3, $22,33$.

Spillane, J. D. (1952). Thorax, 7, 134.

Stössel, E. von (1937). Beitr. Klin. Tuberk., 90, 432.

Thannhauser, S. J. (1950). Lipidoses, 2nd ed., p. $408 . \quad$ Oxford University Press, New York.

Tooth, H. H. (1897). Trans. path. Soc. Lond., 48, 30.

Winternitz M. C. Wason, I. M., and McNamara, F. P. (1920). The Pathology of Influenza, p. 46. Yale University Press, New Haven. 